\title{
Atlantic Water inflow through the Yermak Pass Branch: Evolution since 2007
}

\author{
Camila Artana $^{1,2}$, Christine Provost ${ }^{1}$, Zoé Koenig ${ }^{3,4}$, Marylou Athanase ${ }^{5}$, and \\ Ava Asgari ${ }^{1}$ \\ ${ }^{1}$ Laboratoire LOCEAN-IPSL, Sorbonne Universités (UPMC, University Paris 6), CNRS, IRD, MNHN, \\ Paris, France \\ ${ }^{2}$ Mercator Ocean, Toulouse, France \\ ${ }^{3}$ Norwegian Polar Institute, Fram Centre, 9296 Troms $\varnothing$, Norway \\ ${ }^{4}$ Geophysical Institute and Bjerknes Center for Climate Research, The University of Bergen, Bergen, \\ Norway \\ ${ }^{5}$ Alfred Wegener Institute, Bremerhaven, Germany
}

\section{Key Points:}

- New mooring data in the Yermak Pass Branch documented larger velocity variations (40\%) in 2017-2020 than in 2007.

- Year 2018 stood out with exceptionally ice-free conditions and enhanced eddy activity at the mooring location.

- Synoptic model-based estimate of Atlantic Water volume transport in the Yermak Pass Branch from 2007 to 2020 varies from -1 to 5 Sv. 


\section{Abstract}

Thirty-four months (2017-2020) of mooring data were recently obtained at $80.6^{\circ} \mathrm{N}$, $7.26^{\circ} \mathrm{E}$ in the main branch of Atlantic Water inflow to the Arctic, the Yermak Pass Branch. The Yermak Pass Branch was sampled at that same location during 14 months a decade ago (2007-2008) when sea ice was abundant (mean sea ice concentration of $74 \%$ versus $39 \%$ during the recent deployment). We focus on time-scales larger than 50 hours. The new mooring data set shows an increase in the velocity variations of $40 \%$ compared to the 20072008 period. Year 2018 was exceptional with ice-free conditions over the entire year and an intensified mesoscale activity compared to other years. Temperature and salinity time series at $340 \mathrm{~m}$ showed significant trends over 3 years (freshening of $-0.07 \mathrm{~g} / \mathrm{kg}$ and cooling of about $-0.9^{\circ} \mathrm{C}$ in 3 years). The performance of $1 / 12^{\circ}$ Mercator ocean operational model at the mooring location was precisely assessed. The modelled Atlantic Water transport was on average larger during 2017-2020 (40\% larger) than during 2007-2008. The synoptic transport time series ranged between -1 and 5 Sv over 2007-2020 and showed large seasonal and interannual variations. The transport was larger in winter than summer. However, occasionally negative transport $(<-0.7 \mathrm{~Sv})$ through the Yermak Pass Branch occurred during winters ('Blocking events'). These blocking events are associated with recirculations and eddy activity and were more common over the last years from 2016 onwards. The model suggested that a northern branch crossing the Yermak Plateau further north $\left(81.6^{\circ} \mathrm{N}\right)$ intermittently developed.

\section{Plain Language Summary}

The Atlantic Water flowing through the Fram Strait via the West Spitsbergen Current is the main source of heat and salt for the Arctic Ocean. At the entrance to the Arctic the West Spitsbergen Current splits into several branches as it meets the Yermak Plateau. Thirty four months of observations were recently obtained in the main branch of Atlantic Water inflow to the Arctic, the Yermak Pass Branch. This location used to be ice covered year round. Our results show that the exceptional ice-free conditions in year 2018 were associated with a highly variable flow. An oceanic model, in good agreement with the observations, showed that the Atlantic Water transport through the Yermak Pass Branch was more irregular from 2016 onwards. Changes in the Atlantic Water inflow pathways have important implications for the heat, salt and nutrients reaching the Arctic. 


\section{Introduction}

The Atlantic Water (AW) flows through the Fram Strait via the West Spitsbergen Current (WSC). The AW inflow is the main source of heat and salt for the Arctic Ocean, and plays an important role in the reduction of sea ice (Onarheim et al., 2014; Polyakov et al., 2017) and in the supply of nutrients to the Arctic (Aagaard and Carmack, 1989; Henley et al., 2020). The seasonal variability of the WSC is important, with a stronger flow in winter than in summer (Beszczynska-Möller et al., 2012). The Yermak Plateau located to the northwest of Svalbard is a main obstacle to the warm AW inflow into the Arctic and the WSC splits into several branches as isobaths diverge (Figure 1).

A seasonally varying fraction of the WSC, called recirculation branch ( $\mathrm{rB}$ in Figure 1), recirculates in northern Fram Strait, primarily as eddies, and returns southward (e.g., Teigen et al., 2011; Hattermann et al., 2016; Wekerle et al., 2017). North of Svalbard, the shallow Svalbard Branch (SB in Figure 1b) crosses the Yermak Plateau inshore of the 500m isobath (Cokelet et al., 2008) and lacks seasonality (Koenig, Provost, Sennéchael et al., 2017; Crews et al., 2019). Another branch, the deeper Yermak Branch (YB in Figure 1b) flows along the western edge of the Yermak Plateau roughly following the 1000-m isobath (Manley, 1995) and carries relatively little transport (Koenig, Provost, Sennéchael et al., 2017; Crews et al., 2019).

Koenig, Provost, Sennéchael et al. (2017) highlighted the importance of an additional pathway: the Yermak Pass Branch (YPB in Figure 1b) in which a significant portion of the AW navigates the central plateau following the 700-m isobath, that is northward to $81.2^{\circ} \mathrm{N}$ before turning southeast and rejoining the onshore Svalbard Branch around $10^{\circ} \mathrm{E}$. The Yermak Pass Branch is winter-intensified and is the main route through which AW from the WSC enters the Arctic Ocean. The YPB flow is characterized by strong intermittent flow pulses parallel to isobath of 1-2 month duration in winter (Koenig, Provost, Sennéchael et al., 2017). These intermittent coherent YPB pulses in winter are well reproduced in numerical models (Koenig, Provost, Sennéchael et al., 2017; Crews et al., 2019; Athanase et al., 2021). Crews et al. (2019) found that the winter increase in WSC volume transport is divided between the YPB, dominant earlier in winter when AW is less dense, and Fram Strait recirculations dominant later when AW is denser.

The circulation in this region has been evolving rapidly since 2007 (Athanase et al., 2021). In particular, AW recirculations towards Fram Strait (rB) shifted further north 
while the Yermak Branch (YB) strengthened over the northern Yermak Plateau, occasionally crossing the Plateau north of $81.6^{\circ} \mathrm{N}$ as a branch called Northern Branch (NB, dashed line in Figure 1) hereafter. The strengthening of the AW circulation over and around Yermak Plateau was widespread and coincided with an overall warming in the upper ocean layer $(0-1000 \mathrm{~m})$ (Athanase et al., 2021). As winter sea-ice retreats, the northward progression and shoaling of AW led to enhanced deep winter convection (Athanase et al., 2020). In particular, since 2011, the previously ice-covered central Yermak Plateau occasionally exhibited ice-free conditions in winter,50-m ocean temperatures always above $0^{\circ} \mathrm{C}$, highly variable mixed layer depths and ocean-to-atmosphere heat fluxes, and became a "marginal convection zone" (Athanase et al., 2020). Indeed, during extreme winters, particularly deep convection reached down to the $27.95 \mathrm{~kg} / \mathrm{m}^{3}$ isopycnal (600 $\mathrm{m}$ depth), considerably cooling and freshening the AW layer (Athanase et al., 2020).

A mooring was deployed in the Yermak Pass in 2017, ten years after another pioneering mooring, to document variations in the YPB Atlantic water inflow. We analyze the new 34 month-long times series of temperature, salinity and velocities focusing on time scales larger than 50 hours to examine the recent YPB flow and address changes since 2007 compared to the former observations. The skills of the $1 / 12^{\circ}$ Mercator Ocean operational model in reproducing the new observations are assessed and the 14-year long model time series are used to put the observations into a larger spatial and temporal context. We finally summarize and discuss several hypotheses that could explain the observed variations on both sub-seasonal and interannual scales.

\section{Material}

\subsection{Mooring data}

A mooring was deployed at $80.6^{\circ} \mathrm{N}$ and $7.26^{\circ} \mathrm{E}$, in the Yermak Pass on the eastern flank of the Yermak Plateau, on 15 September 2017 from Norwegian Research Vessel Lance and retrieved on 19 July 2020 from Norwegian Icebreaker K.V. Svalbard. The mooring was only $2.6 \mathrm{~km}$ away from the position of the former 2007 mooring line (Figure $1 \mathrm{~b}$ and 1c).

The 2017 mooring comprised 3 instruments: at about $340 \mathrm{~m}$ an upward-looking RDI 75 kHz Long Ranger Acoustic Doppler Current Profiler (ADCP) measuring velocity profiles (25 bins of $16 \mathrm{~m}$ each), at $348 \mathrm{~m}$ a Seabird SBE37 measuring temperature salinity and pressure, and, at $645 \mathrm{~m}$ an Aquadopp currentmeter (Figure 1c). The current data were corrected from 

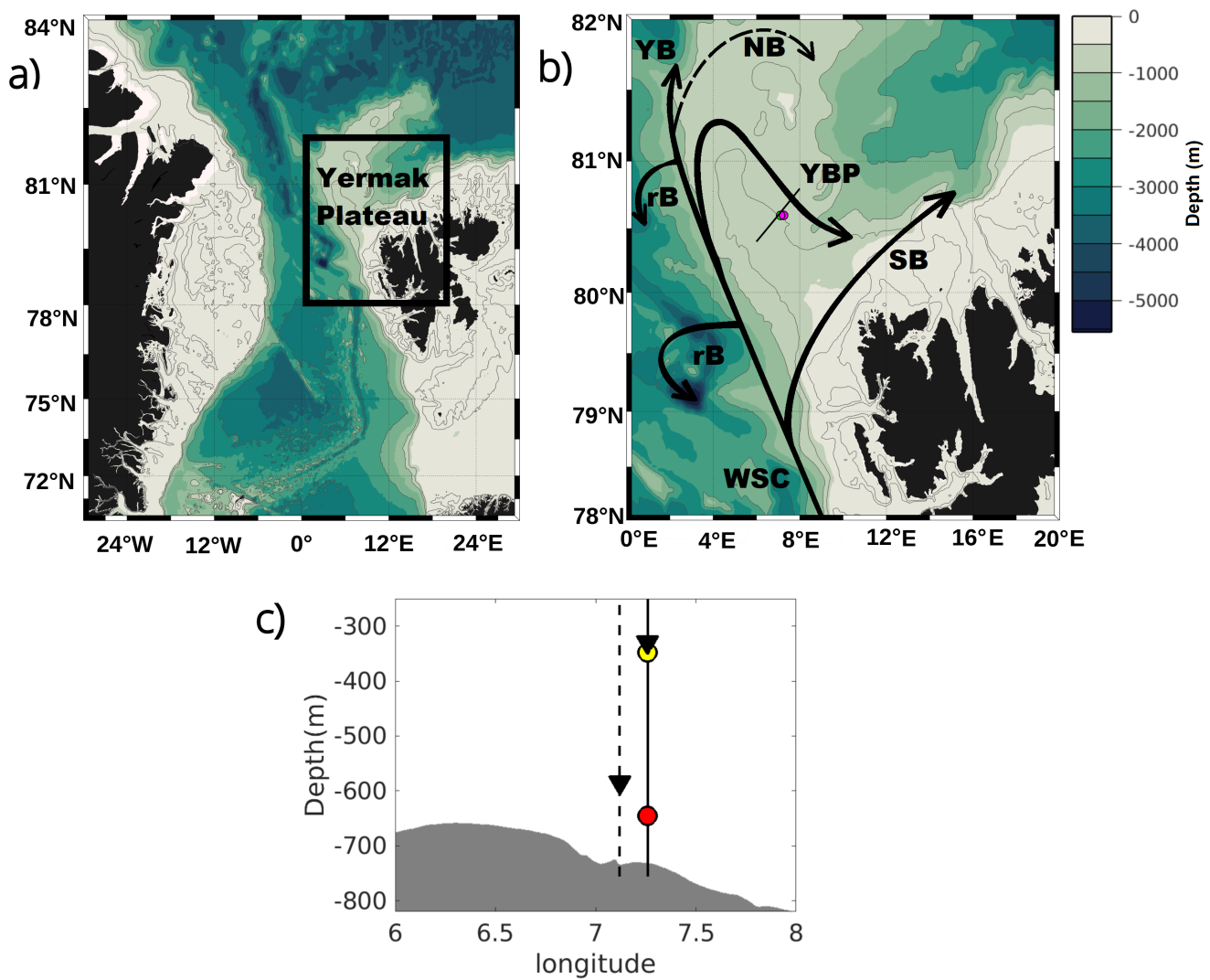

Figure 1. (a) Bathymetry around Fram Strait from IBCAO (Jakobsson et al., 2012). (b) Closeup on the Yermak Plateau. The West Spitsbergen Current (WSC) splits into branches schematized with black arrows: recirculation branches $(\mathrm{rB})$ to the west and south, and four branches navigating over the Yermak Plateau: the Svalbard Branch (SB), the Yermak Pass Branch (YPB), the Yermak Branch (YB) and the Northern Branch (NB) (dashed line) (adapted from Athanase et al., 2021). (c) Schematic of the mooring lines and location along the section shown in (a): the dotted line represents the 2007-2008 mooring carrying an upward-looking ADCP (black triangle) at $585 \mathrm{~m}$, the full line is the 2017-2020 mooring with an aquadopp (red dot) at $645 \mathrm{~m}$, a Seabird microcat (yellow dot) and an upward-looking ADCP at about $340 \mathrm{~m}$ (black triangle). Bathymetry along the section in grey. 


\begin{tabular}{cccccccccccc} 
date & instrument & depth & $\mathrm{U}$ & $\mathrm{V}$ & $\mathrm{T}$ & $\mathrm{S}$ & $\mathrm{P}$ & & $\delta t$ & & $\delta z$ \\
\hline $2017-2020$ & ADCP & $50 \mathrm{~m}$ to $300 \mathrm{~m}$ & $\mathrm{x}$ & $\mathrm{x}$ & $\mathrm{x}$ & & & 2 hours & $16 \mathrm{~m}$ \\
$2017-2020$ & Sea Bird & $348 \mathrm{~m}$ & & & $\mathrm{x}$ & $\mathrm{x}$ & $\mathrm{x}$ & 10 minutes & - \\
$2017-2020$ & Aquadopp & $645 \mathrm{~m}$ & $\mathrm{x}$ & $\mathrm{x}$ & & $\mathrm{x}$ & 2 hours & - \\
\hline $2007-2008$ & ADCP & $250 \mathrm{~m}, 300 \mathrm{~m}, 570 \mathrm{~m}$ & $\mathrm{x}$ & $\mathrm{x}$ & $\mathrm{x}$ & & \multicolumn{2}{c}{2 2 hours } & - \\
\hline
\end{tabular}

Table 1. Sampling specificity of the mooring instruments. U: eastward velocity; V: northward velocity; T: temperature, S: salinity, P: pressure. $\delta t$ : time sampling. $\delta z$ : vertical sampling.

pitch, roll and magnetic declination. All the data (velocities, temperature, and density) have been quality controlled against the ship CTD (Conductivity Temperature Depth) done at the mooring's deployment location and time. Measured variables and sampling interval are summarized in table 1. For the ADCP, the 2 hour sampling resulted from averaging 24 pings obtained every 5 minutes. For the Aquadopp it was a burst sampling every two hours. The seafloor is $730 \mathrm{~m}$ below sea level at the mooring location and rises to $650 \mathrm{~m}$ at the Yermak Plateau crest $10 \mathrm{~km}$ to the west of the mooring (Figure 1c).

The upper $50 \mathrm{~m}$ of the water column were not sampled (Figure 2). The vertical extent of the ADCP data was limited by the paucity of backscattering particles. The data return for all instruments (below $50 \mathrm{~m}$ ) was close to $100 \%$. Indeed, the only data gaps corresponded to $2 \%$ missing data between 100 and $50 \mathrm{~m}$. A linear vertical interpolation was applied to fill the few gaps. Over the 34 months (2017-2020) of measurements, the mooring stayed in a straight position: the Seabird pressure had a mean of $355 \mathrm{db}$ and a standard deviation of $5 \mathrm{db}$ (largest drawdown of $35 \mathrm{db}$ on January 15 2020). We applied a 50-h third-order low-pass Butterworth filter to all time series to remove high frequencies including tide and inertial signals.

The data return of the 2007-2008 mooring was reduced as a malfunctioning ocean profiler stuck on the mooring line above the ADCP reflected part of the acoustic bins (ADCP represented with a black triangle on the dashed line in Figure 1c) (cf. Koenig, Provost, Sennéchael et al., 2017). As a result, the mooring provided complete 14-month long velocity time series at three depths $(250,300$ and $570 \mathrm{~m})$ from 25 July 2007 to 23 September 2008, and there were no measurements of temperature nor salinity time series 

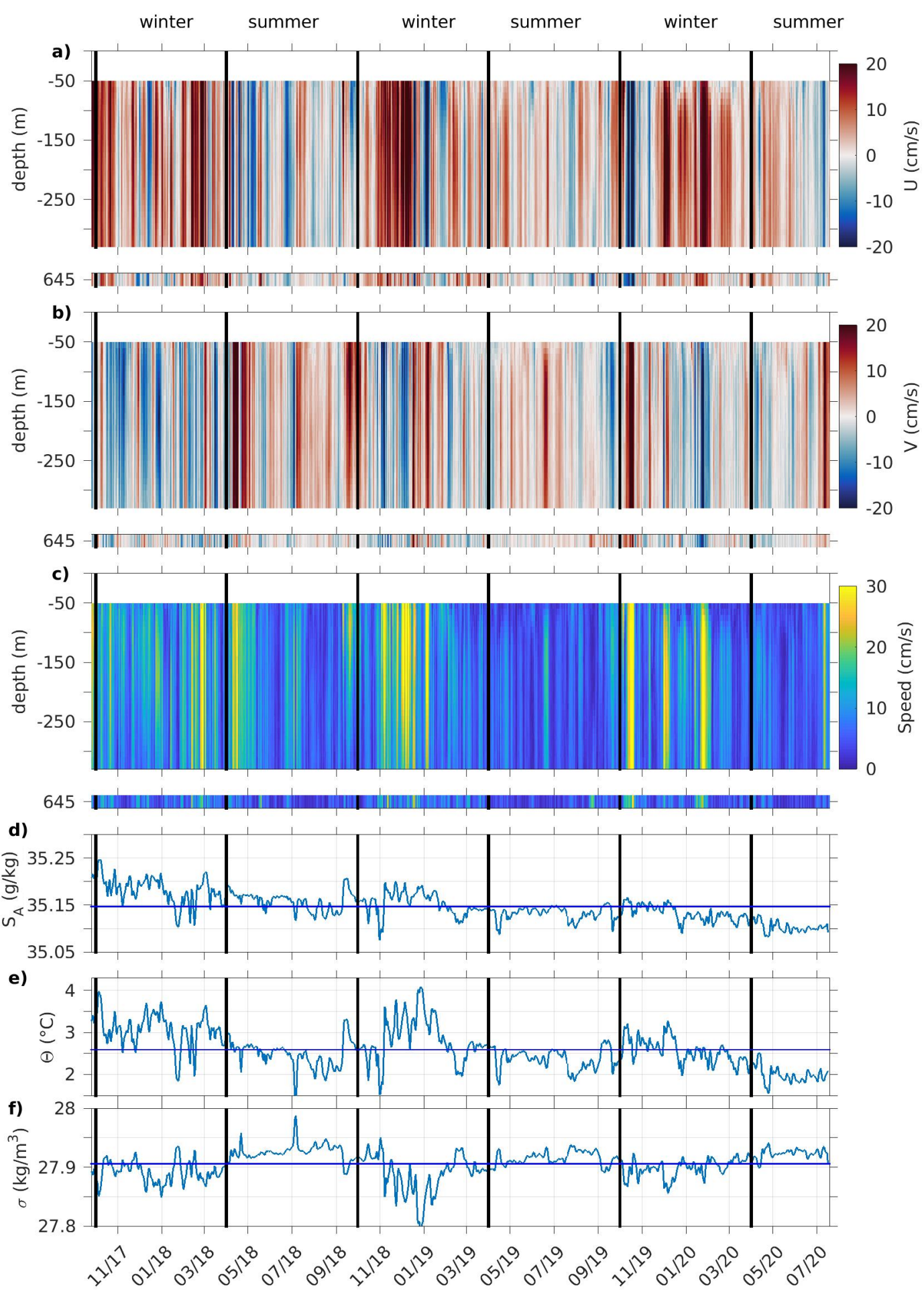

Figure 2. (a) Zonal component of velocity from ADCP (50-330 m profiles) and Aquadopp at 645 m, (b) meridional velocity component (ADCP and Aquadopp) and (c) horizontal speed (ADCP and Aquadopp). (d) Absolute Salinity $S_{A}$, (e) Conservative Temperature $\Theta$ and (f) Potential Density $\sigma$ at $348 \mathrm{~m}$. Blue horizontal lines indicate the mean over the 34 months and black vertical lines delimit the seasons (summer: April to September, winter: October to March). 


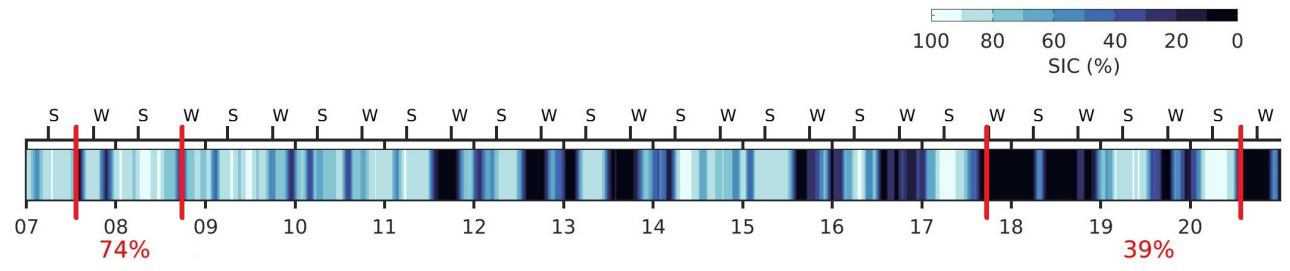

Figure 3. Sea-ice concentration (SIC, \%) at a daily resolution at the mooring location from January 2007 to December 2020. Ticks below the ice concentration indicate years, ticks above mark beginning of seasons (W: winter from October to March, S: summer from April to September). The mooring periods are indicated with vertical red lines. Mean sea ice concentrations over each period are reported in red below.

(Koenig, Provost, Sennéchael et al., 2017) (Table 1). The 50-h low-pass filtered velocities at those three depths are used to address time changes.

In the following, we use the Conservative Temperature $(\Theta)$ and Absolute Salinity $\left(S_{A}\right)$ calculated using the International Thermodynamic Equations of Seawater (TEOS-10) (McDougall et al., 2011).

\subsection{Environmental conditions}

Wind data are from ERA5 reanalysis at $10 \mathrm{~m}$. The wind stress $\tau$ is estimated as follows: $\tau=\rho C_{d} \mathbf{u}|\mathbf{u}|$, where $\rho$ is the air density, $C_{d}$ is the drag coefficient and $\mathbf{u}$ is the wind vector. $C_{d}$ is computed taking into account the sea ice concentration for estimates of $C_{d}$ as given by Lupkes et al., (2005).

Sea-ice concentration are from satellite data (EUMETSAT OSI SAF product at daily temporal resolution, https ://osi-saf.eumetsat.int/products/sea-ice-products).

Sea ice concentration at the mooring location exhibits a seasonal cycle with more ice in early summer (average of $85 \%$ from April to June over the 14 years and 54\% over the full 14 years). Year 2012 marks a diminution in winter sea ice cover (a mean ice cover of $70 \%$ before January 2012 and 54\% afterwards) (Figure 3). Note that summer 2018 is the only ice-free summer of the time series. The mean sea-ice concentration at the mooring location is $74 \%$ during the first deployment (2007-2008) and 39\% during the most recent one (2017-2020). 


\subsection{Mercator-Ocean model (PSY4)}

Within the frame of Copernicus Marine Environment Monitoring Service (CMEMS; http://marine.copernicus.eu/) Mercator Ocean delivers the high resolution $1 / 12^{\circ}$ global operational PSY4 system since January 2007 (Lellouche et al., 2018). The modeling component is based on the NEMO (Nucleus for European Modeling of the Ocean) platform with a $1 / 12^{\circ}$ ORCA grid type (i.e. horizontal resolution of $4 \mathrm{~km}$ in the region) and a water column comprising 50 levels with typically $1 \mathrm{~m}$ resolution at the surface decreasing to 450 $\mathrm{m}$ at the bottom. The forcing atmospheric fields are from the European Centre for Medium Range Weather Forecasts - Integrated Forecast System (ECMWF-IFS) at 3-h resolution. When oceans are ice-covered, only sea ice concentration (EUMETSAT OSI SAF product) is assimilated. This is in stark contrast with the open ocean regions where PSY4 assimilates along-track satellite sea level anomalies, sea surface temperature and in situ vertical profiles of temperature and salinity (Lellouche et al., 2018). The system begins in October 2006 from a "cold" start (initial currents are null and temperature and salinity initial conditions are from EN4.2.1 climatology; Good et al., 2013).

Thorough comparisons of the modelled variables with non-assimilated in situ and satellite data in the western Nansen Basin region demonstrated the model's remarkable performances (e.g. Koenig, Provost, Villacieros-Robineau et al., 2017; Athanase et al., 2019; 2020; 2021) in spite of inherent limitations. Indeed, the model lacks tides which are important on the Yermak Plateau (Koenig, Provost, Sennéchael et al., 2017, Padman et al., 1992). Moreover the model resolution is not fully eddy resolving (grid size of $4 \mathrm{~km}$ and Rossby deformation radius of about $10 \mathrm{~km}$ ) in the region (Richez, 1998; Nurser and Bacon, 2014). Modelled variables will be further compared to the mooring data and PSY4 daily outputs from January 2007 to December 2020 will be used to put the data in a larger spatial and temporal context.

\section{Mooring data analysis}

\subsection{Velocity statistics}

\subsubsection{Velocity means}

Mean velocities averaged over 34 months (2017-2020) ranged between 1.5 and $3.2 \mathrm{~cm} / \mathrm{s}$ in amplitude, the largest value being reached at a depth of $140 \mathrm{~m}$ (Figure 4a). 

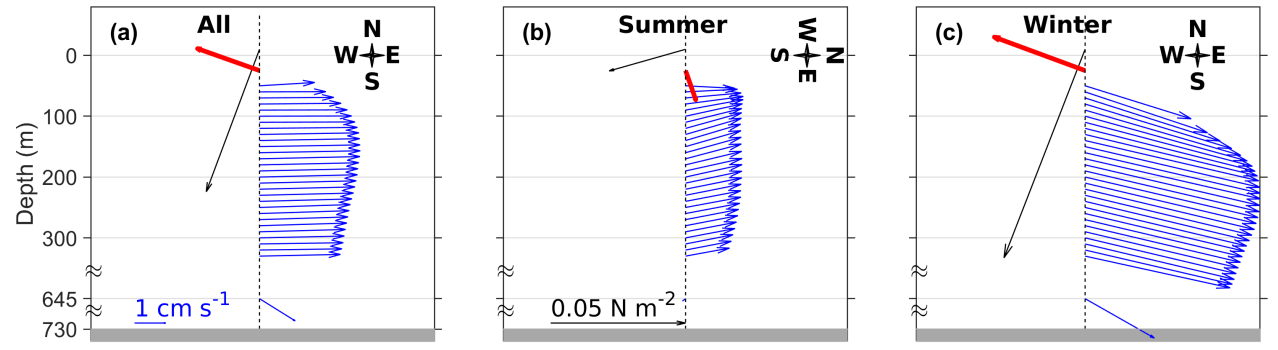

Figure 4. Mean horizontal ocean velocities (blue arrows) as a function of depth over (a) the 34month (2017-2020) long record, (b) summer (April-September), and (c) winter (October-March). The black arrow shows the corresponding mean wind stress at the ocean surface $\left(\mathrm{N} \mathrm{m}^{-2}\right)$. The red arrows at the surface indicate the velocities corresponding to the Ekman transports with the hypothesis of a 20-m deep Ekman layer. Respective vector scales (ocean in blue, air in black) are indicated in panel (a) and (b). For sake of clarity, the compass is rotated to the right by $90^{\circ}$ in (b). The tildes in the y-axis marks the depth gap between Aquadopp and ADCP and the Aquadopp and the seafloor. Seafloor is at $730 \mathrm{~m}$.

Mean velocities have the same general direction (eastward), the upper levels (40 to 120 m) being slightly more to the northeast and the lower level more to the southeast (Figure $4 a)$.

The mean velocities vary seasonally, with smaller velocities in summer (maximum of 1.7 $\mathrm{cm} / \mathrm{s}$ from 80 to $230 \mathrm{~m}$ ) (Figure $4 \mathrm{~b}$ ). Summer mean velocities exhibit a northward direction except at the upper levels (48-120 m) (northwestward), and are close to zero at the lower $645 \mathrm{~m}$ level (Figure 4b). In winter, mean velocities are larger (reaching $5.7 \mathrm{~cm} / \mathrm{s}$ at $160 \mathrm{~m}$ ) and roughly in the southeastward direction, that is parallel to isobaths (Figure 4c).

Mean winds are northeasterlies (black arrows in Figure 4), larger in winter than in summer. They induce a mean Ekman transport (red arrows in Figure 4) to the northwest opposite to the mean ocean flow, likely contributing to the smaller mean ocean velocities in the upper layer.

Seasonal mean velocities show large interannual variations in amplitude and direction as illustrated by the velocity means and variance ellipses during the summer (April to September) and winter (October to March) seasons produced for each year of available data (Figure 5). 
Only three levels were fully sampled in the 2007-2008 data set: 250, 300 and $570 \mathrm{~m}$ (Table 1). As the $570 \mathrm{~m}$ is not sampled in the recent data set, it was compared to the closest available level that is $645 \mathrm{~m}$ (Figure 1c). The data ensemble covers three complete summers and four complete winters. Upper level velocities (shown at $100 \mathrm{~m}$ in Figures 5a and 5b) are only available in the recent data set.

\begin{tabular}{c|ccc|cccc} 
& \multicolumn{3}{|c|}{ Summer } & \multicolumn{4}{c}{ Winter } \\
& 2008 & 2018 & 2019 & $2007-08$ & $2017-18$ & $2018-19$ & $2019-20$ \\
\hline Mean ice concentration (\%) & 76 & 10 & 61 & 72 & 0.7 & 49 & 49 \\
\hline $\bar{V} / \mathrm{a}($ in cm/s) at $100 \mathrm{~m}$ & - & $4.3 / 8.0$ & $1.6 / 5.1$ & - & $7.4 / 8.9$ & $4.8 / 13.2$ & $4.3 / 12.3$ \\
$\bar{V} / \mathrm{a}($ in cm/s) at $250 \mathrm{~m}$ & $4.7 / 4.3$ & $3.8 / 7.4$ & $1.7 / 4.6$ & $3.4 / 7.9$ & $7.1 / 8.1$ & $4.5 / 10.6$ & $4.6 / 11.7$ \\
$\bar{V} / \mathrm{a}($ in $\mathrm{cm} / \mathrm{s}$ ) at $570-645 \mathrm{~m}$ & $2.7 / 2.1$ & $0.4 / 4.7$ & $1.2 / 4.6$ & $1.1 / 5.2$ & $2.5 / 6.9$ & $3.3 / 7.1$ & $1.8 / 8.4$ \\
\hline
\end{tabular}

Table 2. Seasonal statistics: mean ice concentration at the mooring location, mean velocity $\bar{V}$ and half-length $a$ of the major axis of velocity variance ellipses at selected depths.

Summer velocities means tend to be directed toward the north when above $1 \mathrm{~cm} / \mathrm{s}$ in amplitude, and are overall smaller than winter means, except for summer 2008 (red in Figure 5) which exhibits the largest summer mean (Table 2). Winter velocity means during the second deployment have a southeastward direction parallel to isobaths as the AW flow pulses identified in Koenig, Provost, Senéchael et al., (2017) (means in excess of $4 \mathrm{~cm} / \mathrm{s}$ at 100 and $250 \mathrm{~m}$ Table 2 and Figures 5b and 5d) while winter means in 2008 are smaller and perpendicular to isobaths (red in Figure 5d; Table 2).

\subsubsection{Horizontal velocity variations}

Velocity variance ellipses reveal the magnitude, principal direction and anisotropic nature of the flow variability. In general velocity variance ellipses are significantly smaller in summer than in winter (Figure 5, Table 2) and the major axes are parallel to isobaths in all seasons (Figure 5). Striking exceptions are ellipses from the ice-free summer 2018 which are large and round (yellow in Figure 5a and 5c) and from winter 2017-18 which have a main axis in zonal direction (yellow in Figure 5b and 5d). Year 2008 (red in Figure 5) features the smallest velocity variance ellipses in all seasons (Table 2). 

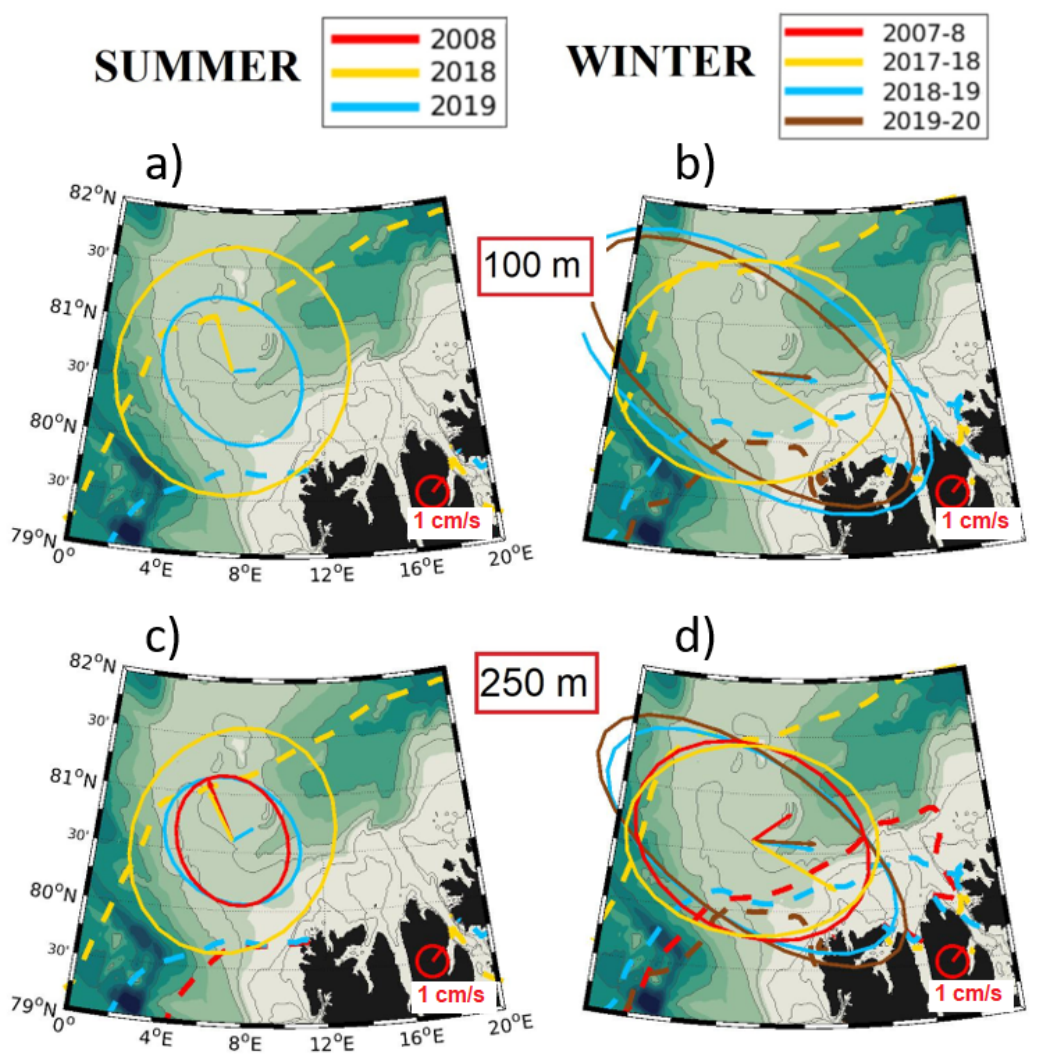

d)
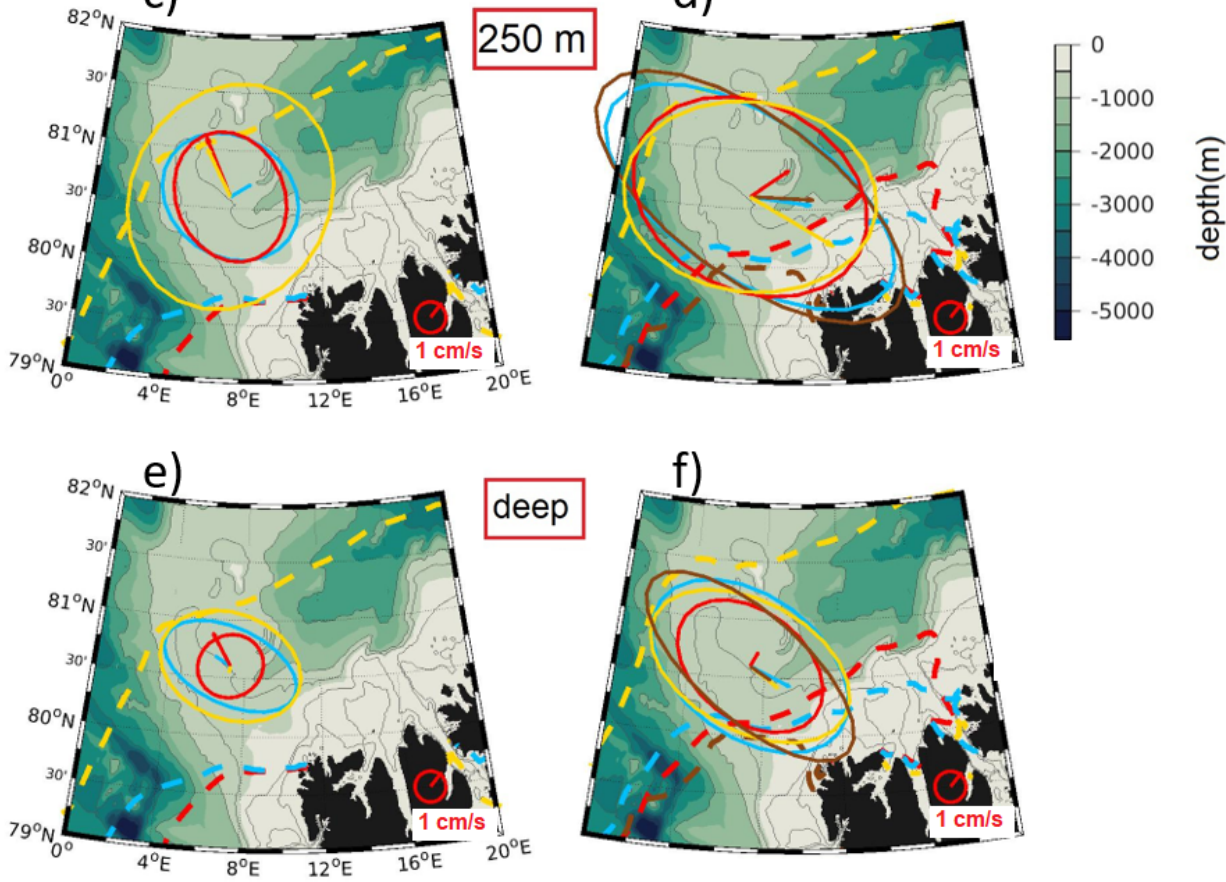

Figure 5. Means and variance ellipses of 50-h filtered horizontal velocities for summer (April to September, left panels) and winter (October to March, right panels) at (a), (b) 100 m; (c), (d) 250 $\mathrm{m}$; and (e), (f) the deepest levels (570 and $645 \mathrm{~m})$. Colors correspond to years: red is first mooring deployment (2007-08), yellow is year 2017-18, blue is 2018-19, and brown is 2019-20. Thick dashed lines are the mean sea-ice edge (defined as the $20 \%$ sea-ice concentration) over the corresponding seasons and years (same color code). 
Velocities from the exceptional ice-free summer 2018 result in a larger variance ellipse at all depths (yellow in Figures 5a, 5c, 5e) compared to ice covered summer 2008 and 2019 (red and blue respectively). Winters 2018-19 and 2019-20, with a mean ice cover of 49\% at the mooring location, exhibit elongated velocity variance ellipses with the largest major axes in excess of $20 \mathrm{~cm} / \mathrm{s}$ (brown and blue in Figures 5b, 5d, 5f; Table 2).

The mooring was located close to the marginal ice zone, with the ice-pack to the north. The wind direction in summer 2018 was predominantly from the East (direction from 45$90^{\circ}$ with respect to north) (Figure $6 \mathrm{~b}$ ), thus favorable to pushing the ice away to the north and providing ice-free conditions at the mooring location. Indeed the mean sea-ice edge in summer 2018 (yellow dashed line in Figures 5a, 5c, and 5e) is located to the North of $81^{\circ} \mathrm{N}$ at the mooring longitude. In contrast, northwesterlies like in summer 2008 and 2019 (Figure $6 \mathrm{a}$ and $6 \mathrm{c}$ ) bring ice to the area and the sea-ice edge is south of $80^{\circ} \mathrm{N}$ (red and blue dashed lines in Figures 5a, 5c, and 5e). This is consistent with the ice conditions reported in Figure 3

Generally the strong winter winds are favorable to pushing the ice away (Figures 6d to $6 \mathrm{~g}$ ) and the region just to the north of Svalbard known as Whalers Bay is ice free. The particularly ice-free winter 2017-18 at the mooring location (cf. Figure 3) corresponds to a mean sea-ice edge north of $81^{\circ} \mathrm{N}$ at the mooring longitude (yellow dashed line Figures $5 \mathrm{~b}$, 5c, and 5f). Winter 2017-18 features even more easterlies and southerlies (Figure 6e) both favorable to pushing the ice away.

In contrast, the mean sea-ice edge in winters 2007-08 and 2018-19 (red and blue dashed lines in Figures 5b, 5d, and 5f) remained south of the mooring although north of their summer location (Figures 5a, 5c, and 5e). Winter 2019-20 stands out as the winter with the southernmost mean ice edge location (brown dashed line in Figures 5b, 5d, and 5f) associated with a prevalence of northerlies and northwesterlies (Figure $6 \mathrm{~g}$ ).

The size of the winter ellipses do not bear any obvious relation with the sea-ice edge as the winter 2019-20 features the largest winter ellipses and the southernmost ice edge (Figures 5b, 5d, 5c). These results are consistent with Lundesgaard et al. (2021) who showed that anomalous sea-ice years (over 2012-2019) in the Atlantic water inflow region west and north of Svalbard are associated with anomalies in atmospheric circulation and ice advection. They argued that although ocean heat maintains ice-free conditions in the Atlantic inflow 

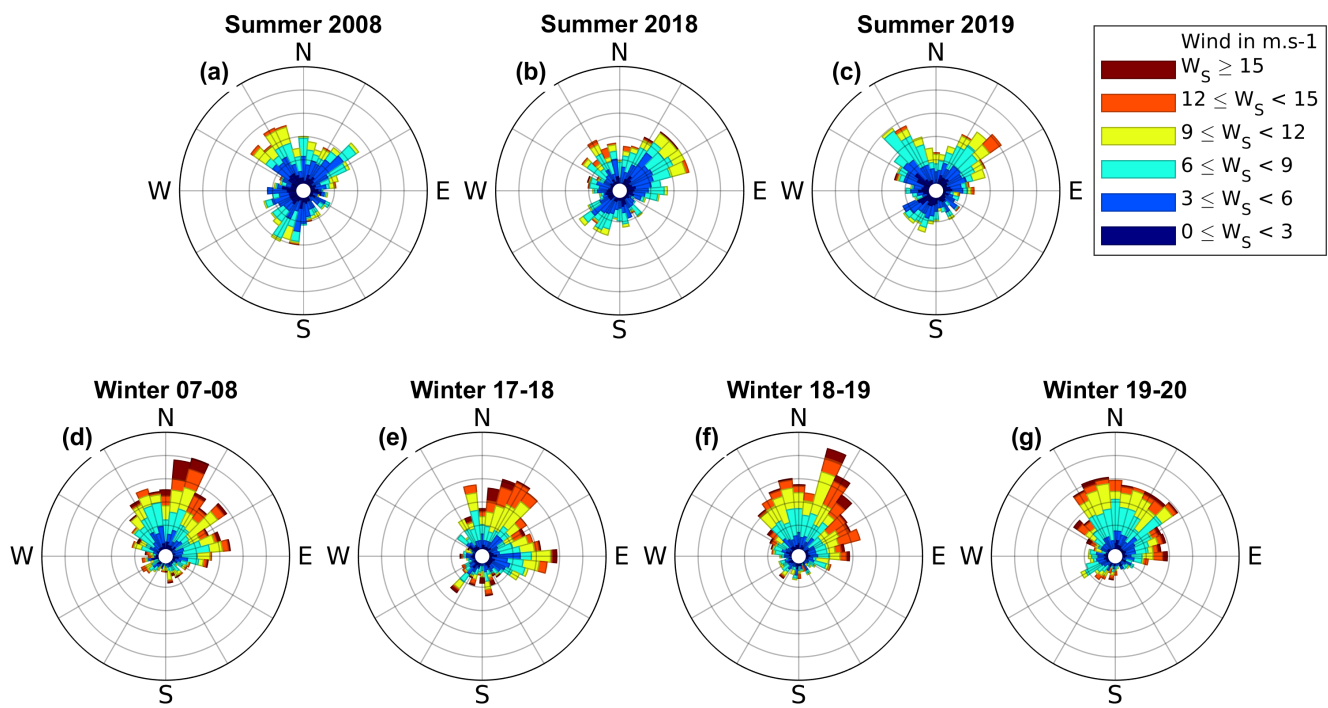

Figure 6. Wind roses for: (a) summer 2008, (b) summer 2018, (c) summer 2019, and (d) winter 2007-08, (e) winter 2017-18, (f) winter 2018-19, (g) winter 2019-20. The outside circle is $10 \%$ occurrence and inner circles mark every $2 \%$.

region during winter, interannual sea ice variability was not driven by changes in ocean heat during 2012-2019.

The 50-h filtered velocity time series feature variations at smaller than seasonal time scales (Figure 2) that are examined next.

\subsection{Eddy Activity in the Yermak Pass}

Rotary spectra of the 50-h filtered velocities (ADCP and aquadopp) showed rather similar energy levels for cyclonic and anticyclonic motions, although cyclonic motions were in general slightly more energetic than anticyclonic motions at all periods in the $330-50 \mathrm{~m}$ depth range (Table 3 and Supplementary S1).

In contrast, near the seafloor two period bands (3-7 days and 25-50 days) showed more energy in anticyclonic motions (Table 3).

Seasonal rotary spectra are presented at two levels available for both the former (20072008, 300 and $570 \mathrm{~m})$ and recent (2017-2020, $300 \mathrm{~m}$ and $645 \mathrm{~m}$ ) moorings (full and dashed lines in Figure 7). 


\begin{tabular}{cccccccc} 
Period & 3 to 5 days & 5 to 10 days & 10 to 25 days & 25 to 50 days & 50 to 100 days & $>100$ days \\
\hline $300 \mathrm{~m}$ & 1.2 & 1.6 & 1.1 & 1.7 & 1.2 & 1.1 \\
\hline $645 \mathrm{~m}$ & 0.7 & 1.1 & 1.4 & 0.9 & 1.2 & 1.1 \\
\hline
\end{tabular}

Table 3. Ratio of cyclonic (CCW) to anticyclonic (CW) energy as a function of periods at 300 and $645 \mathrm{~m}$ for the second deployment (2017-2020)

The ice-free summer 2018 stands out with more energy (both CW and CCW) at all periods than other summers at $300 \mathrm{~m}$ depth (full yellow curve in Figures 7a and 7b) resulting in the largest ellipse (shown in yellow in Figure 5c). Rather heavily ice-covered summer 200708 shows low levels of energy ( 5 times smaller) at periods larger than 8 days (both CCW and $\mathrm{CW}$ ) at depth (dashed red lines in Figures $7 \mathrm{a}$ and $7 \mathrm{~b}$, small red ellipse in Figure 5e). There is more energy in anticyclonic motions between 20 and 40 days at $300 \mathrm{~m}$ in recent summers compared to summer 2008, while no difference is observed for cyclonic motions (Figures $7 \mathrm{a}$ and $7 \mathrm{~b}$ ).

At periods less than 8 days, the winter rotary spectra at $300 \mathrm{~m}$ and at the deepest levels show similar energy levels for all years in CW (clockwise) and CCW (counterclockwise) (Figures $7 \mathrm{c}$ and $7 \mathrm{~d}$ ). There is more energy at $300 \mathrm{~m}$ than at the deepest level (both $\mathrm{CW}$ and $\mathrm{CCW}$ ) at periods larger than 8 days.

Differences between years in winter are subtle although variance ellipses are rather dissimilar (Figures 5b, 5d, 5f). Winter ellipses in 2018-19 and 2019-20 are elongated along isobaths and reflect large pulses to the south-east (Figure 5d) while winter ellipses for 201718 are more round and reflect more isotropic variations. The ice-free winter 2017-18, with round-shaped ellipses, exhibits more cyclonic energy in the 10 to 20-day and 2 to 5-day period bands (yellow in Figure 7d). On the other hand, compared to winter 2017-18 the winters 2018-19 and 2019-20 show more energy (both CW and CCW) at periods larger than 30 days, probably associated with AW pulses along topography.

At the deepest level, there is more energy at periods larger than 8 days during the recent years (dashed lines in Figure 7). This is consistent with the smaller ellipses of year 2007-2008 (red ellipses in Figures 5e and 5f). This may be related with a thicker AW layer in recent years as described in Athanase et al. (2021). 

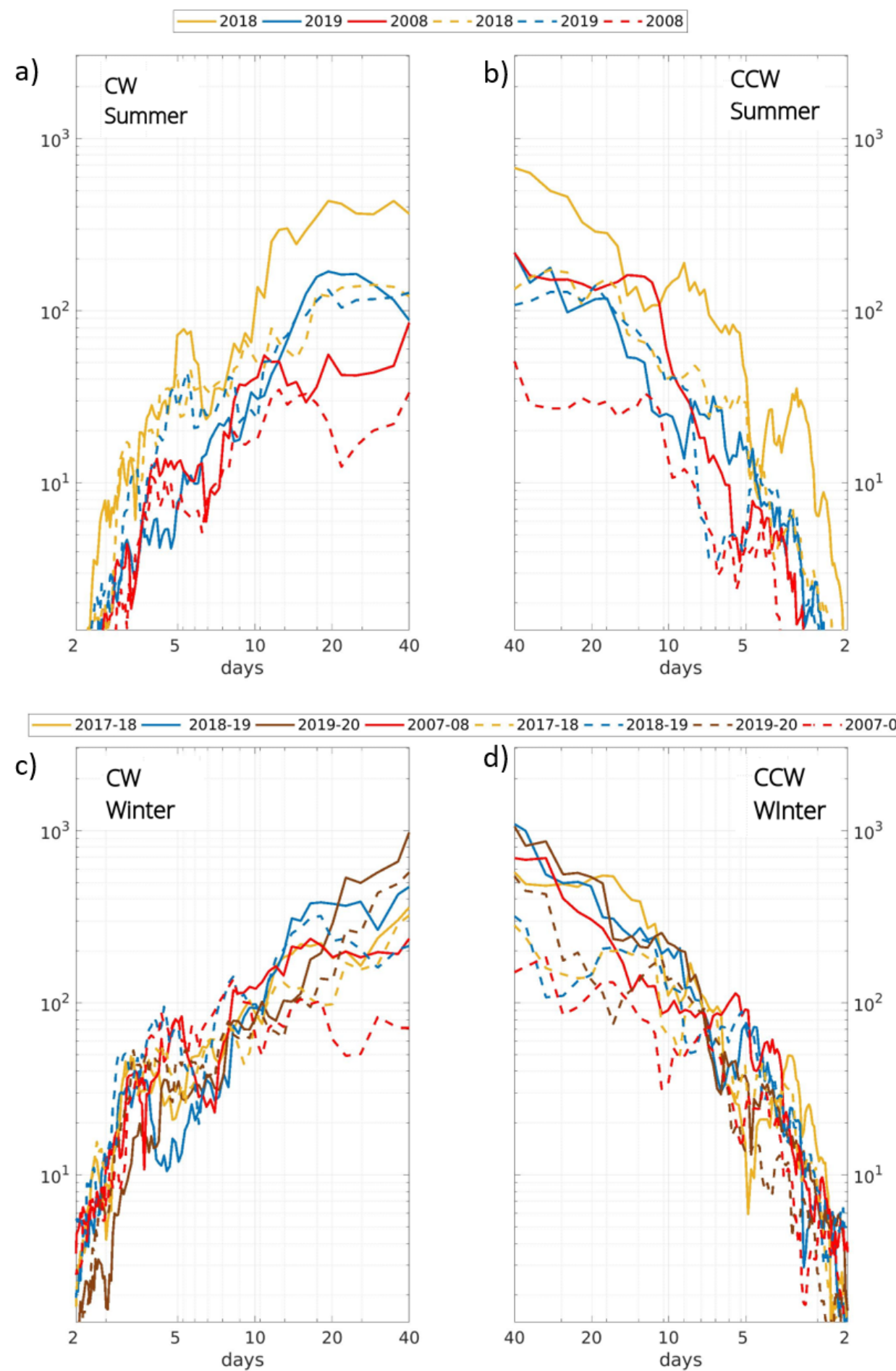

Figure 7. Rotary spectra of horizontal velocities at $300 \mathrm{~m}$ (full line) and at the deepest level (645 $\mathrm{m}$ for 2017-2020 and $570 \mathrm{~m}$ for 2007-2008 in dashed line) averaging over groups of 4 adjacent frequencies (50-h filtered velocities with $2 \mathrm{~h}$ resolution). Color indicate years, as in Figure 5. (a), (b) Summer spectra; (c), (d) Winter spectra. X-axis is the period in days and $\mathrm{y}$-axis is the energy in $\mathrm{cm}^{2} / \mathrm{s}^{2}$. 

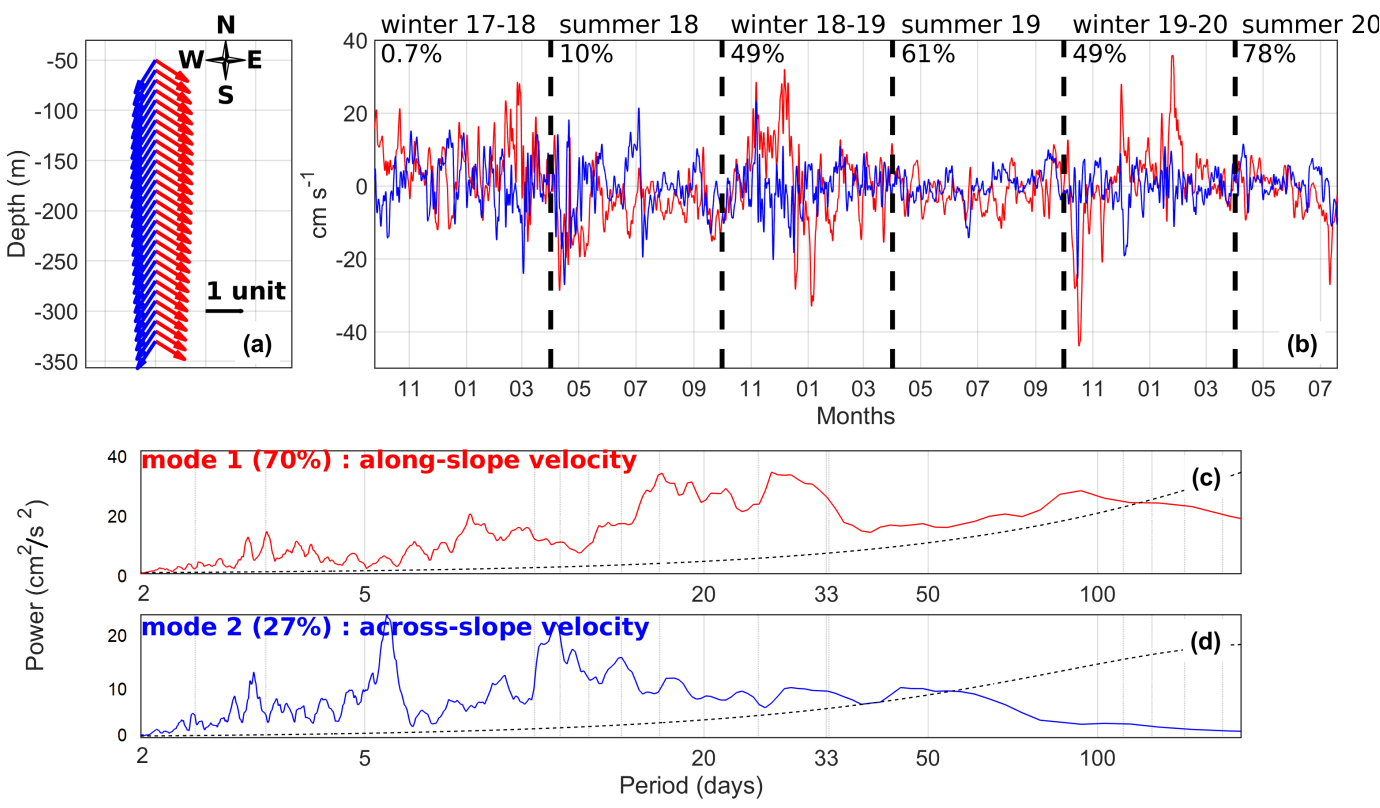

Figure 8. Empirical orthogonal function (EOF) decomposition of the 50-h filtered horizontal velocities with a $2 \mathrm{~h}$ resolution: first mode, parallel to isobaths, (explaining $70 \%$ of the variance) in red, second mode, perpendicular to isobaths, $(27 \%)$ in blue: (a) vertical structure and (b) associated time series. (c), (d) Variance-preserving spectra of the EOFs time series (averaging over groups of 10 adjacent frequencies). The dotted lines show the $95 \%$ confidence level. Y-axis units are $\mathrm{cm}^{2} / \mathrm{s}^{2}$. Percentages in black in (b) indicate mean seasonal ice-concentration.

\subsection{Modes of horizontal velocity variations}

An empirical orthogonal function (EOF) analysis was performed on the 50-h filtered horizontal velocity data from the ADCP. The first two modes accounted for $97 \%$ of the velocity variance (Figure 8).

The first and second modes (respectively $70 \%$ and $27 \%$ of the total variance, in red and blue in Figure 8) are close to a barotropic structure with the same direction in the vertical (slightly subsurface intensified) (Figure 8a). Mode 1 is parallel to isobaths while mode 2 is perpendicular to isobaths.

The EOF time series featured distinct spectral contents with significant broad band energy until 140 days for the first mode (hereafter EOF1) and 60 days for the second mode (EOF2) (Figures 8c, 8d). EOF1 showed salient peaks at 16, 30 and 90 days and EOF2 at 3.5, 6 and 11 days (Figures $8 \mathrm{c}, 8 \mathrm{~d}$ ). 
The first mode EOF1 can be interpreted as pulses of AW through the Yermak Pass in the direction parallel to isobaths. Those pulses have large energy peaks at periods between 15-day and a month (Figure 8c). The higher frequency peaks of the second mode EOF2 (peaks at 6 and 11 days, blue in Figure 8d) could be the signature of mesoscale activity. Indeed, drifting floats at $300 \mathrm{~m}$ depth documented vortices with rotating time scales of 5 to 15 days, curvature radius of about $4 \mathrm{~km}$ and tangential speed of $10 \mathrm{~cm} / \mathrm{s}$ in the Yermak Pass area (Gascard et al., 1995 and Richez, 1998). EOF1 also bears the signal of mesoscale activity at time scales smaller than 20 days (Figure 8c).

The time series associated with the EOFs are not stationary: they show little fluctuations from February to October 2019 and from February to July 2020 (Figure 8b) which correspond to large sea ice concentration at the mooring site (Figure 3). In contrast, the EOFs time series, especially EOF2, exhibit important variations during the ice-free summer 2018 (Figure 8b) in accordance with the corresponding large variance ellipses and large eddy kinetic energy (yellow in Figure 5a, 5c and 7c, 7d).

The extreme event on the 7 October 2019 (EOF1 reaching $-50 \mathrm{~cm} / \mathrm{s}$ and EOF $2+25 \mathrm{~cm} / \mathrm{s}$ Figure $8 \mathrm{~b}$ ) corresponds to a northwestward flow (Figure 2). Koenig, Provost, VillacierosRobineau et al. (2017) showed that northwestward velocities in the YPB were frequent in summer, however to our knowledge it is the first time that such a large (about $30 \mathrm{~cm} / \mathrm{s}$ ) and prolonged (about 3 weeks) northwestward YPB flow is recorded in winter.

\subsection{Temperature and salinity variations}

At $348 \mathrm{~m}$ depth, conservative temperature ranges between 4 and $1^{\circ} \mathrm{C}$, absolute salinity between 35.07 and $35.25 \mathrm{~g} / \mathrm{kg}$ (Figures $2 \mathrm{~d}$ and $2 \mathrm{e}$ ). These values fall within the Atlantic Water property range with $\Theta>1^{\circ} \mathrm{C}$ and $S_{A}>35.05 \mathrm{~g} / \mathrm{kg}$ (e.g. Perez-Hernandez et al. (2019). The two time series feature significant (above the $99 \%$ confidence level threshold) negative trends of about $0.9^{\circ} \mathrm{C}$ and $0.08 \mathrm{~g} / \mathrm{kg}$ in 3 years (Figures $2 \mathrm{~d}$ and $2 \mathrm{e}$ ). Mercator model PSY4 also features this freshening trend and cooling trends over 2017-2020 (Athanase et al., 2021).

Salinity, temperature and density time series show larger and more variable values in winter than in summer (Figures 2d, 2e and 2f, Table 4). Water is denser in summer (colder and fresher) than in winter (warmer and saltier) (Figure 2f, Table 4). 
a)

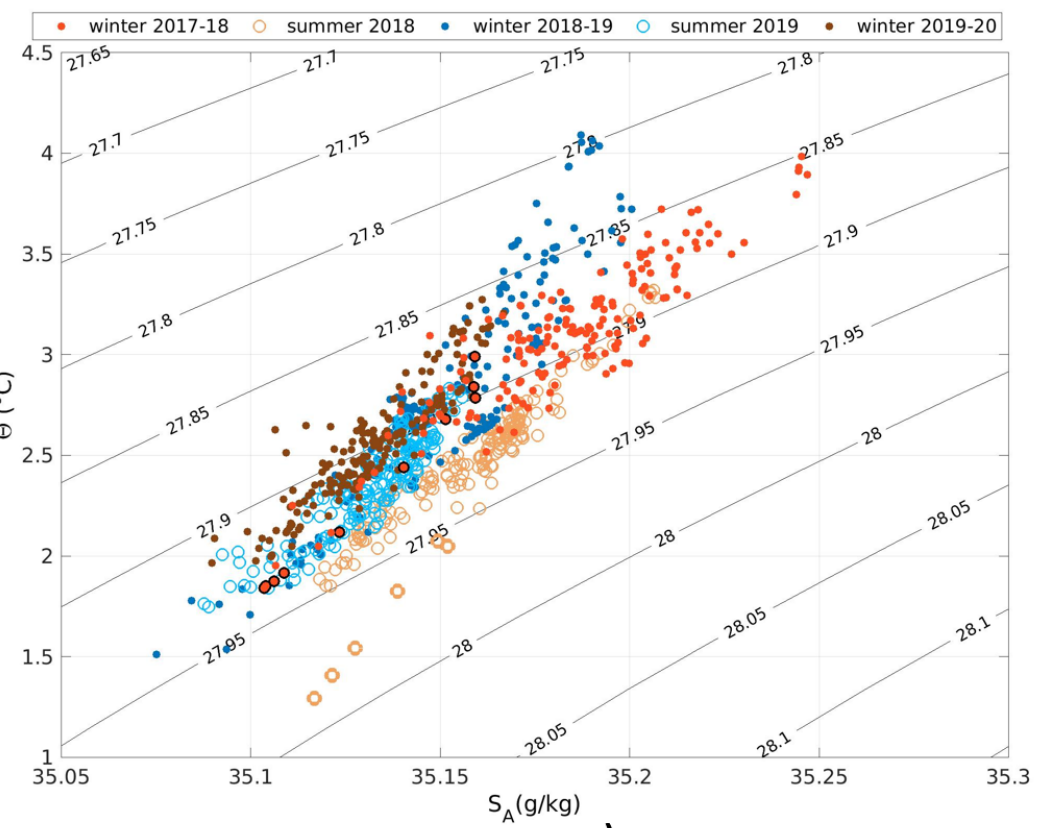

b)
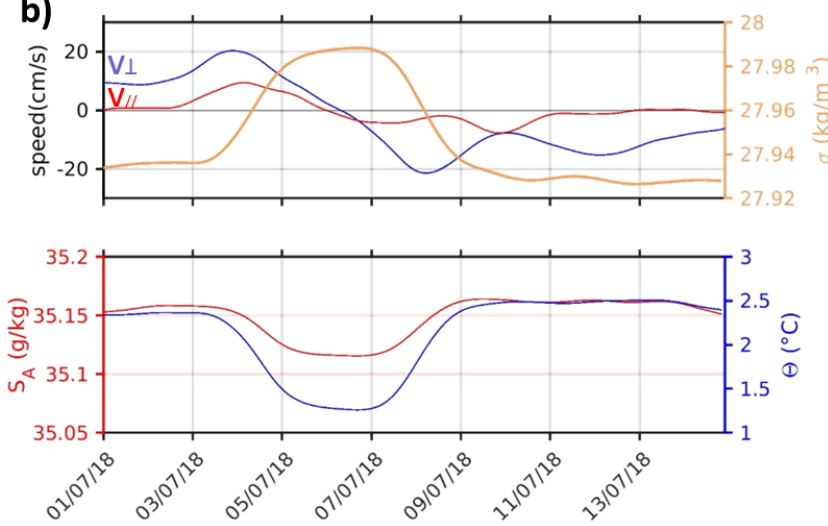

c)
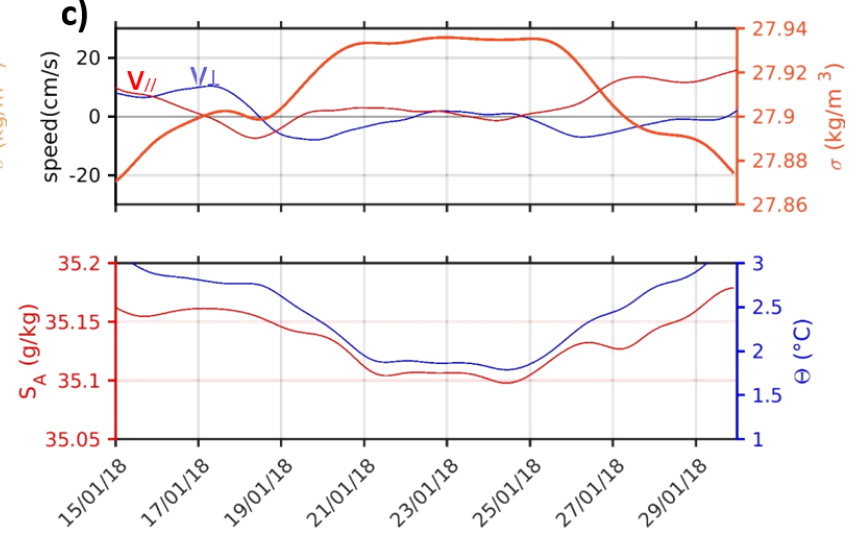

Figure 9. (a) $\Theta / S_{A}$ diagram at $348 \mathrm{~m}$ (50-h low-pass filtered data and daily resampled): full dots are winter data (October-March) and circles summer data (April-September). Colors indicate years: 2017-2018 in orange, 2018-2019 in blue and 2019-2020 in brown. (b) Time series of along and across slope velocities (rotation of $+40^{\circ}$ ), density $(\sigma)$, absolute salinity $\left(S_{A}\right)$ and conservative temperature $(\theta)$ for early July 2018 corresponding to the light orange circles with densities larger than $27.95 \mathrm{~kg} / \mathrm{m}^{3}$. (c) Same as (b) for mid-January 2018. The corresponding dark orange dots in the $\Theta / S_{A}$ diagram are highlighted with a black edge. 


\begin{tabular}{l|c|cccccc}
\hline & SIC (\%) & $\bar{\Theta}(\mathrm{STD})$ & $\Theta \min / \max$ & $\overline{S_{A}}(\mathrm{STD})$ & $S_{A} \min / \max$ & $\bar{\sigma}(\mathrm{STD})$ & $\sigma \min / \max$ \\
\hline summer 2018 & 10 & $2.47(0.32)$ & $1.29 / 3.31$ & $35.15(0.02)$ & $35.11 / 35.20$ & $27.92(0.01)$ & $27.88 / 27.98$ \\
\hline summer 2019 & 61 & $2.36(0.23)$ & $1.74 / 2.83$ & $35.13(0.01)$ & $35.08 / 35.15$ & $27.91(0.01)$ & $27.89 / 27.93$ \\
\hline winter 2017-18 & 0.7 & $3.05(0.39)$ & $1.84 / 3.98$ & $35.18(0.03)$ & $35.10 / 35.24$ & $27.89(0.01)$ & $27.84 / 27.93$ \\
\hline winter 2018-19 & 49 & $2.83(0.53)$ & $1.51 / 4.08$ & $35.15(0.02)$ & $35.07 / 35.20$ & $27.88(0.03)$ & $27.79 / 27.95$ \\
\hline winter 2019-20 & 49 & $2.55(0.29)$ & $1.96 / 3.27$ & $35.13(0.01)$ & $35.08 / 35.16$ & $27.89(0.01)$ & $27.85 / 27.92$ \\
\hline
\end{tabular}

Table 4. Statistics of conservative temperature $\left({ }^{\circ} \mathrm{C}\right)$, absolute salinity $(\mathrm{g} / \mathrm{kg})$ and density $\left(\mathrm{kg} / \mathrm{m}^{3}\right)$ at $348 \mathrm{~m}$ as a function of seasons: means, standard deviation (STD) and extrema (minima and maxima). The first column recalls sea ice concentration (SIC).

The $\Theta / S_{A}$ diagram illustrates further the cooling and freshening trend over the three years (orange dots are from 2017-2018, blue dots from 2018-2019 and brown dots from 20192020) (Figure 9a). The diagram also reflects that on average at $348 \mathrm{~m}$, water is denser in summer than in winter (Figure 9a).

The densest points in the diagram $\left(\sigma>27.95 \mathrm{~kg} / \mathrm{m}^{3}\right)$ likely correspond to a cold core structure (eddy or meander) $\left(\mathrm{T}<1.5^{\circ} \mathrm{C}\right)$ crossing the mooring in summer 2018 between July 3 and 10 (Figure 9b). During this event, velocity components changed sign while temperature was minimum (Figure 9b). Salinity in the structure core was smaller $(35.12 \mathrm{~g} / \mathrm{kg}$ ) than in surrounding waters $(>35.15 \mathrm{~g} / \mathrm{kg})$ and velocities exceeded $20 \mathrm{~cm} / \mathrm{s}$ at the structure core boundary (Figure 9b). This event is revisited in section 5 .

During the second half of January 2018 (Figure 9c), the temperature dropped from $3.2^{\circ} \mathrm{C}$ to $1.6^{\circ} \mathrm{C}$ and salinity from 35.15 to $35.1 \mathrm{~g} / \mathrm{kg}$ while density increased from 27.88 to $27.94 \mathrm{~kg} / \mathrm{m}^{3}$ (Figure 9c). This corresponds to a deep convective event further described in section 5 .

The EOF1 of velocity variations and temperature (or density) time series (detrended or not) are correlated ( $\mathrm{r}=+0.2$ for temperature, 0.25 for density, both significant at the $90 \%$ confidence level): intense southeastward pulses tend to carry rather warm and light waters. This is congruent with Crews et al. (2019). The correlations although significant are modest 
as deep winter convective events cool the Atlantic Water (e.g. Athanase et al., 2020; section $5)$.

\section{Yermak Pass Branch in Mercator-Ocean operational model}

\subsection{Further model assessment: comparison with the 2017-2020 data}

Comparisons between co-localized PSY4 variables and 10-day smoothed mooring observations are shown in Supplementary S2. We recall the main results. PSY4 temperature and salinity reproduce well the mean and variations of the 10-day smoothed in situ time series at $348 \mathrm{~m}$. PSY4 is on average $0.3^{\circ} \mathrm{C}$ warmer $\left(2.9^{\circ} \mathrm{C}\right.$ versus $\left.2.6^{\circ} \mathrm{C}\right)$ and $0.03 \mathrm{~g} / \mathrm{kg}$ saltier $(35.18$ versus $35.15 \mathrm{~g} / \mathrm{kg})$. Model standard deviations (STD) are on the same order $\left(0.4^{\circ} \mathrm{C}\right.$ and 0.03 $\mathrm{g} / \mathrm{kg})$ as observations and variations are correlated at the $99 \%$ significance level $(\mathrm{r}=0.68)$ (Supplementary S2). The model reproduces the observed decreasing trends in salinity and temperature. This comparison is performed with a longer time series than in Athanase et al. (2021) and leads to the same conclusions.

Comparisons between model velocities and observations (Supplementary S2) suggest that differences in mean velocities can probably be attributed to the lack of tide representation in the model. Tides are large over the Yermak Plateau and induce a residual current of about $4 \mathrm{~cm} / \mathrm{s}$ to the north (Koenig, Provost, Sennéchael et al., 2017). The residual current is present in the in-situ mean velocity and absent the model mean.

Model velocity variance ellipses are smaller than those resulting from the 20-day filtered observed velocities: in summer the great axes are about $50 \%$ smaller and in winter only $10 \%$ smaller (Supplementary). Indeed, the $1 / 12^{\circ}$ grid resolution of the model does not fully resolve the eddy scale in the region (Rossby radius of about $10 \mathrm{~km}$; Crews et al., 2018).

An EOF decomposition of the model velocity over the ADCP range was performed (model velocities were interpolated to the ADCP vertical resolution). The first two modes of the EOF are similar in structure to those from the ADCP and explain 85 and $13 \%$ of the variance respectively (Figure 10). The first mode (EOF1, parallel to the isobaths) represents the pulses while the second mode (EOF2, perpendicular to the isobaths) is associated with the weak model eddy field.

Correlation between EOF1 of model horizontal velocities and (50-h filtered) ADCP velocity is 0.43 (above the $99.9 \%$ confidence level) showing that the model does represent 

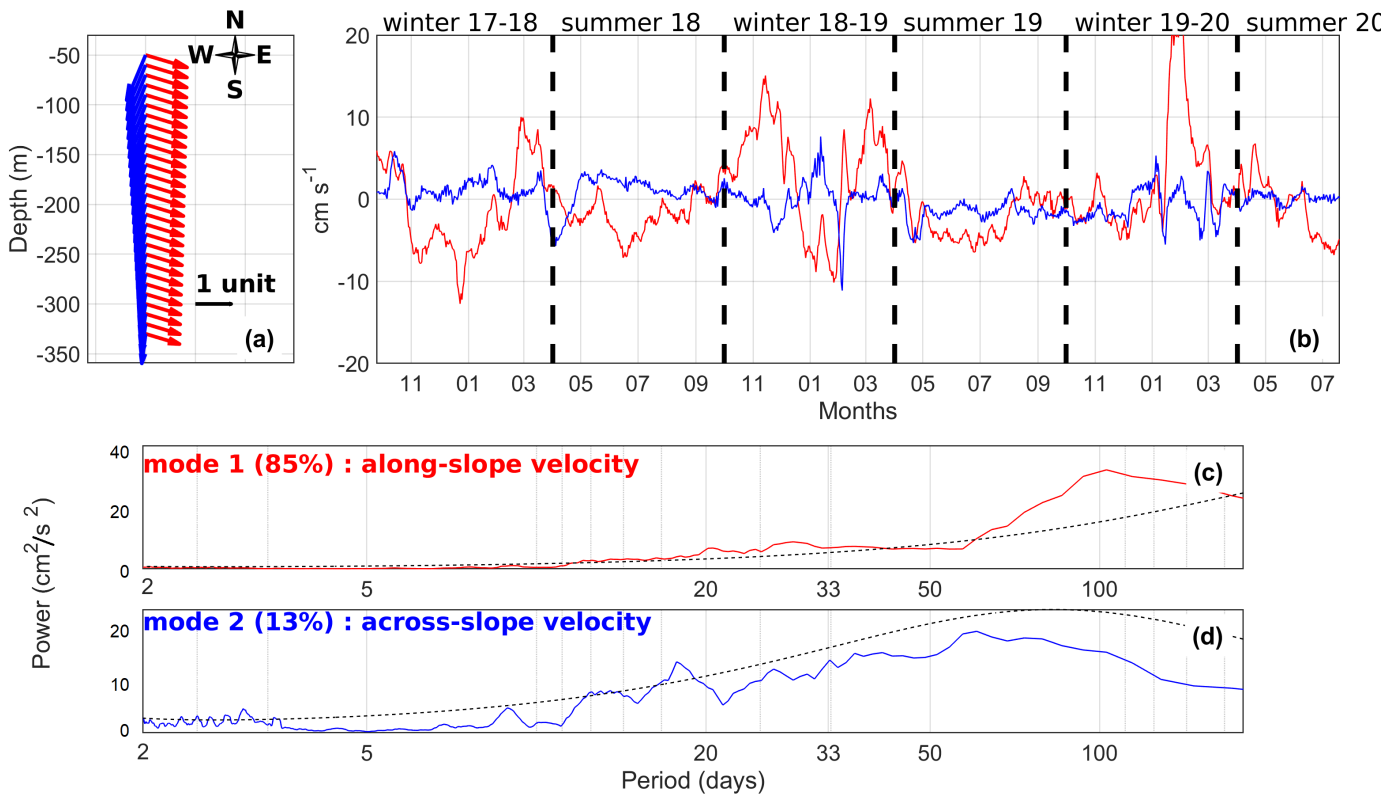

Figure 10. (a) Vertical structure of EOF1 and EOF2 of model daily velocities over the ADCP range. (b) EOF1 and EOF2 time series. (c) and (d) Variance-preserving spectra of the EOFs time series (averaging over groups of 10 adjacent frequencies). The dotted lines show the $95 \%$ confidence level. Y-axis units in $\mathrm{cm}^{2} / \mathrm{s}^{2}$.

the major current pulses with some skill. Although levels of energy are smaller and energized periods slightly longer, the spectral contents of the time series have a distribution rather similar to those of the data EOFs with energy at 23, 30 and 128 days (EOF1) and 17 days (EOF2) (Figure 10).

The model EOF1 does represent some of the negative events present in the ADCP EOF1 such as the one in late December 2017 or late January 2019 (Figure 10b). The model velocity field at $266 \mathrm{~m}$ on 22 December 2017 features an anticyclonic eddy tangential to the mooring location and suggests that some of these negative events correspond to an intensified mesoscale eddy field (Figure 11). The Yermak Branch, flowing northward along the western edge of the Plateau, was particularly intensified at that time and feeding a Northern Branch (NB in Figure 1b) crossing the Yermak Plateau north of $81.8^{\circ} \mathrm{N}$ (Athanase et al, 2021) (Figure 11).

These stringent comparisons illustrate the model capabilities in representing water mass properties and velocity (in spite of a smaller velocity variance). 
a)

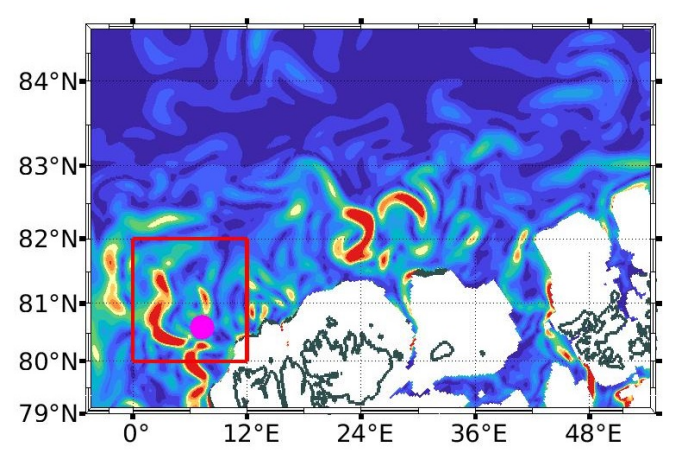

b)

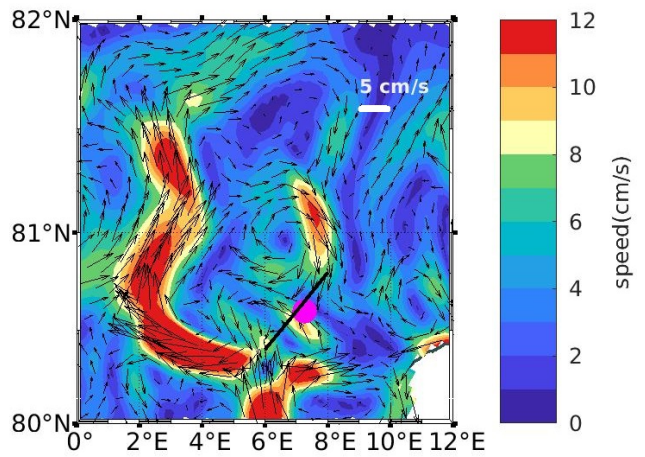

Figure 11. (a) PSY4 horizontal velocities at $266 \mathrm{~m}$ on the 22 December 2017 in the Western Nansen Basin, with (b) a close up on the Yermak Plateau (red box in a). Color scale in cm/s. For sake of clarity velocity vectors are only plotted in (b) and every other grid point. Magenta dot indicates the mooring location and black line is the section used to compute the AW transprt. Green contours are isobaths.

\subsection{Evolution of the Yermak Pass Branch over the last 14 years in PSY4}

Model velocity means over the two mooring periods at $266 \mathrm{~m}$ (Figures $12 \mathrm{a}$ and 12b) illustrate an intensified circulation (more northward reaching) during the second period (20172020) consistent with the schematics of circulation changes from Athanase et al. (2021). A close-up around the Yermak Plateau during the recent mooring period features a recirculation branch shifted to the north by 1 degree latitude, a stronger Yermak Branch (along the western side of Yermak Plateau) reaching further north, an intensified Yermak Pass Branch and a new branch (Northern Branch) crossing the Yermak Plateau at $81.8^{\circ} \mathrm{N}$ around a seamount located north of the YPB (Figure 12b).

Atlantic water transport associated with the modelled Yermak Pass branch (YPB) was computed across the section shown in Figure 12 in two ways: net transport as in Koenig, Provost, Sennéchael et al. (2017) and "positive velocity only" transport only taking into account positive cross-section velocities as in Perez-Hernandez et al. (2019). The mean net transport $(1 \mathrm{~Sv})$ is only $0.1 \mathrm{~Sv}$ smaller than the "positive velocity only" transport and the two time series are highly correlated $(r=0.98$, Figure $13 \mathrm{a}$ with the net transport in red, and "positive velocity only" transport in blue). In addition the two transport time series are highly correlated with EOF1 time series (Figure 10b, $r=0.97$ ) suggesting that 
a)

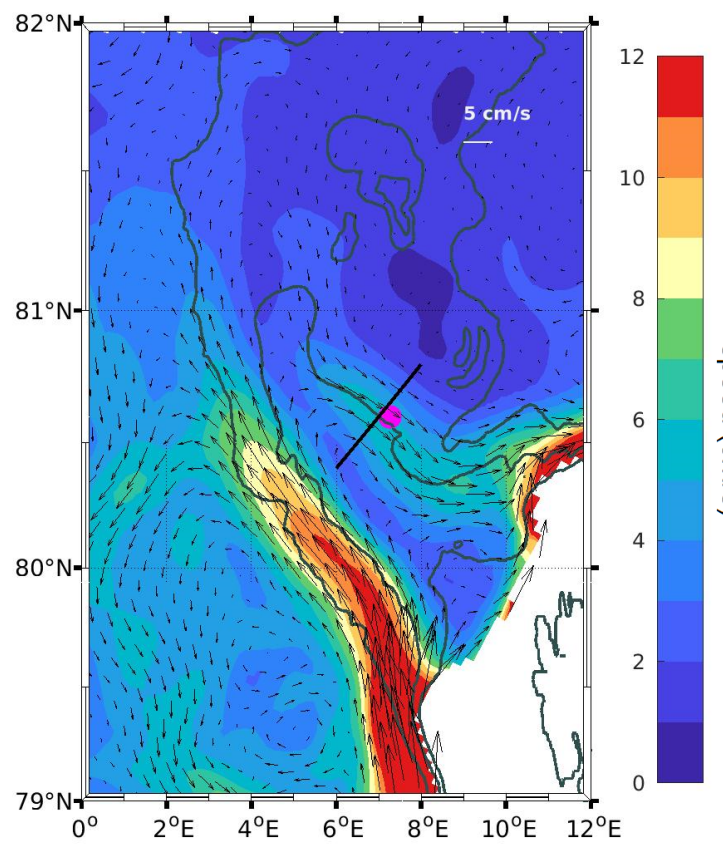

b)

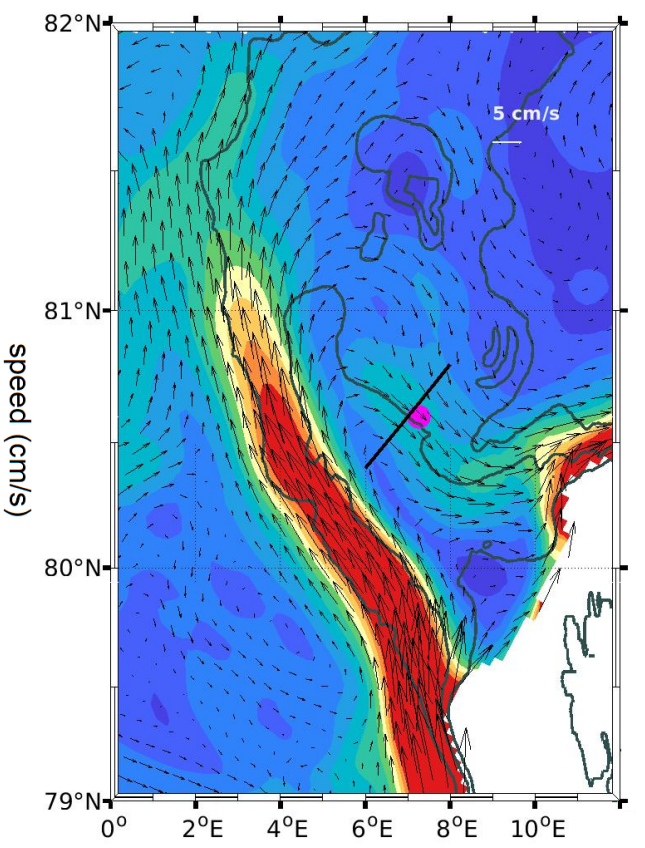

Figure 12. PSY4 horizontal velocities at $266 \mathrm{~m}$ averaged over (a) 2007-2008 and (b) 2017-2020 (full years). Background color is current speed in $\mathrm{cm} / \mathrm{s}$. The magenta dot indicates the mooring location and the black line is the section used to compute the AW transport. The green contours are isobaths. 
the mooring location is well spotted at least in the model. The spectral content of the volume transport features a strong seasonal cycle (maximum transport in winter) and large interannual variations as shown in the wavelet transform amplitude (Figure 13b). Year 2016 marks a change in the spectral content: before 2016 energy is concentrated around the annual period whereas after 2016 significant energy is found over a large range of periods from bi-annual to 50 days (Figure 13b).

The mean AW volume transport through Yermak Pass (positive velocities only) is 0.7 Sv during the first mooring deployment and $1.04 \mathrm{~Sv}$ during the second one (close to the 14-year mean value of $1.13 \mathrm{~Sv}$ ) (Figure 13). Transport STD increased from 0.6 Sv during first deployment to $0.9 \mathrm{~Sv}$ during second deployment.

However, the AW transport means do not reflect a linear trend as they are both below the 14 year average, and interannual and seasonal variations are large (Figure 13 and Supplementary S3). In particular, the maximum annual mean transport $(1.7 \mathrm{~Sv})$ is reached in 2013/2014 and minima (about 0.7 Sv) in recent years are observed in 2015/16 and 2017/18 (Supplementary S3). Changes in AW transport through the YPB are modulated by changes in the West Spitsbergen Current (WSC) transport itself and the distribution of WSC transport among the different branches (Figure 1): Svalbard Branch, Yermak Pass Branch, Yermak Branch, Northern Branch and recirculation branches (Athanase et al., 2021). The modeled YPB constitutes the main path for AW over the Yermak Plateau with an AW volume transport largely correlated with the West Spitsbergen Current AW transport $(\mathrm{r}=0.75)$ (Athanase et al., 2021). Model suggests that the maximum in 2013/14 can be attributed to a smaller recirculation back to Fram Strait (thus more flow through the YPB) and minima in 2015/16 and 2017/18 to a larger recirculation (thus less flow through the YPB) (Athanase et al., 2021; their Figure 5). PSY4 was consistent with recent moorings on the prime meridian which also indicated that $\mathrm{AW}$ recirculations showed a maximum at $80^{\circ} \mathrm{N}$ in winter 2017 (Hofmann et al., 2021).

\section{Discussion}

The Mercator Ocean model proved its reliable performance and provided consistence with measurements insights on the large variations of the Yermak Pass Branch. We used the model to put observations in a larger spatio-temporal context. 
a)

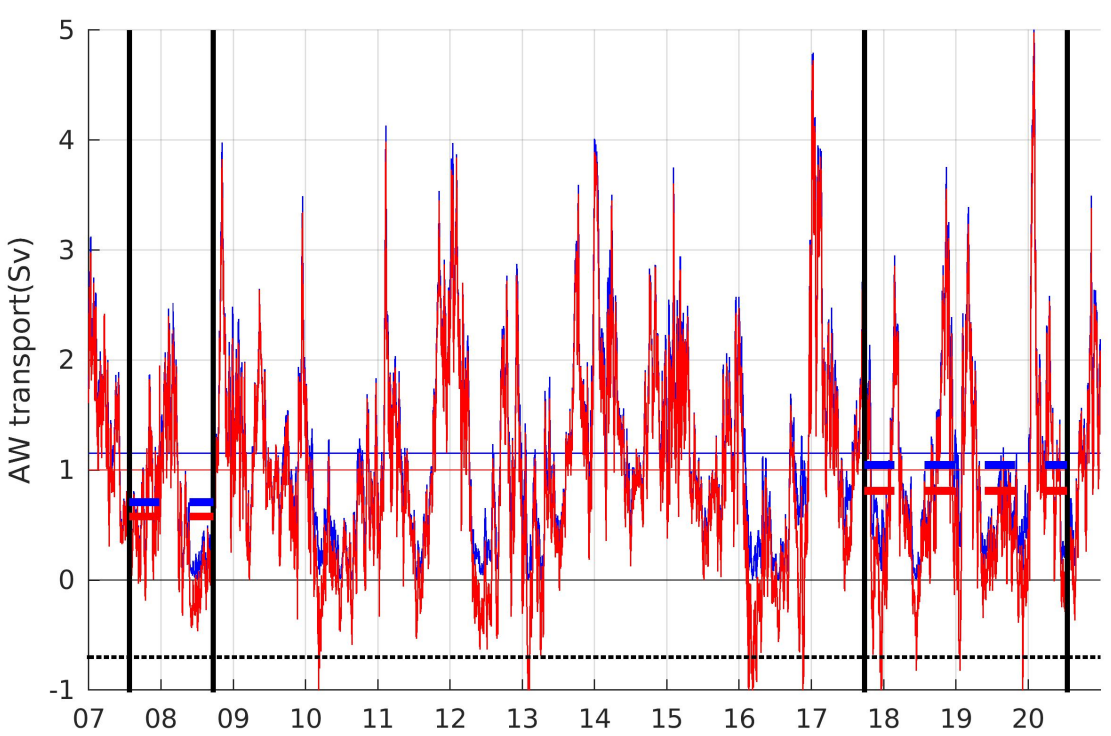

b)

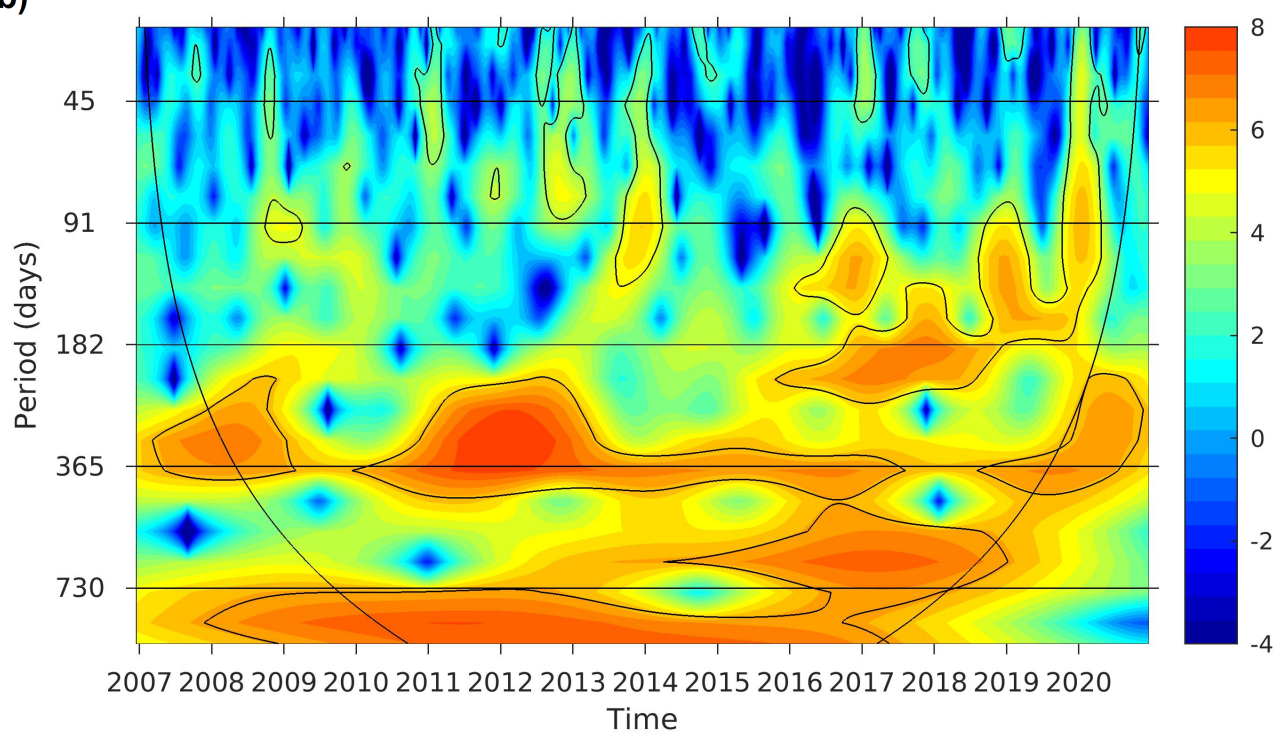

Figure 13. (a) 14-year time series of $\mathrm{AW}\left(\Theta>1^{\circ} \mathrm{C}, S_{A}>35.05 \mathrm{~g} / \mathrm{kg}\right)$ volume transport (Sv) across the Yermak Pass branch section shown in Figure 1b: net transport in red and "positive crosssection velocity only" in blue (see text). The two periods with mooring data are delimited and their respective mean transport indicated with dashed horizontal lines. The black dotted horizontal line marks the $-0.7 \mathrm{~Sv}$ value. (b) Wavelet of net transport time series shown in base 2 logarithm; The black contours is the $95 \%$ confidence level; $\mathrm{y}$ axis is the period in days and $\mathrm{x}$ axis is the time in years. 
a)

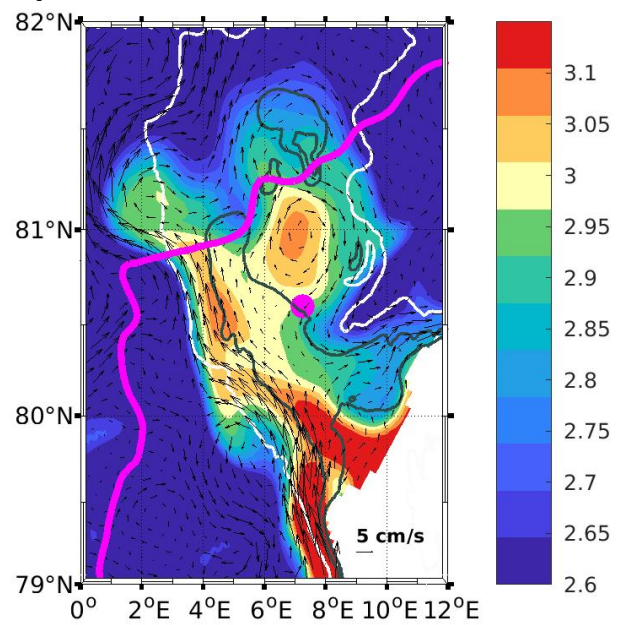

b)

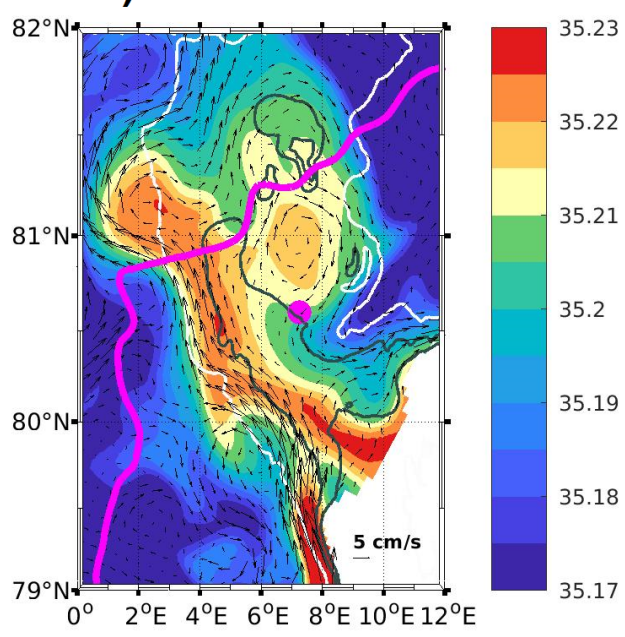

Figure 14. (a) Model $\Theta\left({ }^{\circ} \mathrm{C}\right)$ and (b) $S_{A}(\mathrm{~g} / \mathrm{kg})$ at $318 \mathrm{~m}$ on the first July 2018. Arrows indicate velocities at that depth. The magenta contour marks the synoptic ice edge and the white contour the 1000-m isobath. Magenta dot indicates the mooring location. Dark green contours are 700-m and 500-m isobaths

\subsection{Water mass properties at $348 \mathrm{~m}$}

There was no temperature nor salinity times series recorded in 2007-2008. The 20172020 mooring data documented the seasonality and recent evolution of AW properties at $348 \mathrm{~m}$ depth in the YPB. Density changes were temperature-driven, and the AW water in the YPB was denser in summer (colder and fresher) than in winter (warmer and saltier), confirming model-based results from Crews et al. (2019). The densest waters at $348 \mathrm{~m}$ were recorded early July 2018 and corresponded to a cold and rather fresh cyclonic structure during ice-free summer 2018 (Figures 9a and 9b). Interestingly, PSY4 fields from that date suggest that the cyclonic structure was a sharp meander bringing colder and fresher waters from the Sofia Deep towards the mooring site (Figure 14). In the model, the sharp meander, located to the south of a large anticyclone near the ice edge, followed the slope of a canyon-like structure (see isobath $1000 \mathrm{~m}$ in Figure 14).

Mooring time-series of temperature, salinity and density at $348 \mathrm{~m}$ exhibited larger variations in winter than in summer (Figures $2 \mathrm{~d}, 2 \mathrm{e}, 2 \mathrm{f}$, and Table 3 ). This is congruent with a larger mesoscale activity in winter and occurrence of deep winter convection. 
The dense event observed in January 2018 (Figure 9c) was also documented in PSY4 (Figures S2, 15) and occurred at a time of deep convection. Indeed, times series of PSY4 fields at the mooring location outline the exceptional conditions early 2018 with a net heat flux of $-400 \mathrm{~W} / \mathrm{m}^{2}$ during 3 months and mixed layers exceeding $400 \mathrm{~m}$ in depth (Figure 15). Those convective conditions resulted in homogeneous waters (same water properties at 40 and $380 \mathrm{~m}$ ) and cooler, fresher and denser AW (Figure 15). According to PSY4, the deep mixed layer lasted until April when northerly winds pushed the ice back over the mooring (not shown). These were the deepest (and most long-lasting) mixed layers in the 14-year time series at the mooring location (Figure 15). Athanase et al. (2020) showed how winters in early 2013 and early 2018 were outstanding with the deepest mixed layers and exceptional sea-ice retreat on the slope and Yermak Plateau, respectively. Winter ventilation of the AW layer through winter convection is a rather localized phenomenon in time and space as it requires near-surface AW inflow, and appropriate forcing (wind pushing the ice away and large negative heat fluxes; e.g., Ivanov et al., 2018, Koenig, Provost, Villacieros-Robineau et al., 2017).

A notable freshening of the YPB Atlantic Water was recorded over the 2017-2020 period ( $-0.080 \mathrm{~g} / \mathrm{kg}$ in 3 years) and was also reproduced by PSY4 $(-0.087 \mathrm{~g} / \mathrm{kg}$ in 3 years; Supplementary S2). The 14-year long salinity time series from PSY4 suggests that the trend started late 2016 in the YPB (Figure 15). The freshening trend likely resulted from the poleward advection of fresh anomalies from the North Atlantic (Mork et al., 2010; Holliday et al., 2020). The data at $348 \mathrm{~m}$ also displayed a significant negative temperature trend $\left(-0.90^{\circ} \mathrm{C}\right.$ in 3 years $)$ which PSY4 also reproduced $\left(-0.63^{\circ} \mathrm{C}\right.$ in 3 years; Supplementary S2). PSY4 shows that over 14 years the temperature trend in YPB is not significant (Athanase et al., 2021; Figure 15). PSY4 time series after the mooring recovery (April 2020) shows an increase in temperature and salinity which suggest that the 3-year trends could be temporary (Figure 15). However, caution is required with such a short time series.

\subsection{Velocities and volume transports}

A major result was the intensification of the increased variability of summer velocities in 2017-2020 compared to 2007-2008 (Figure 5). Overall the main axes of the velocity variance ellipses increased by about $40 \%$ (Table 2). 


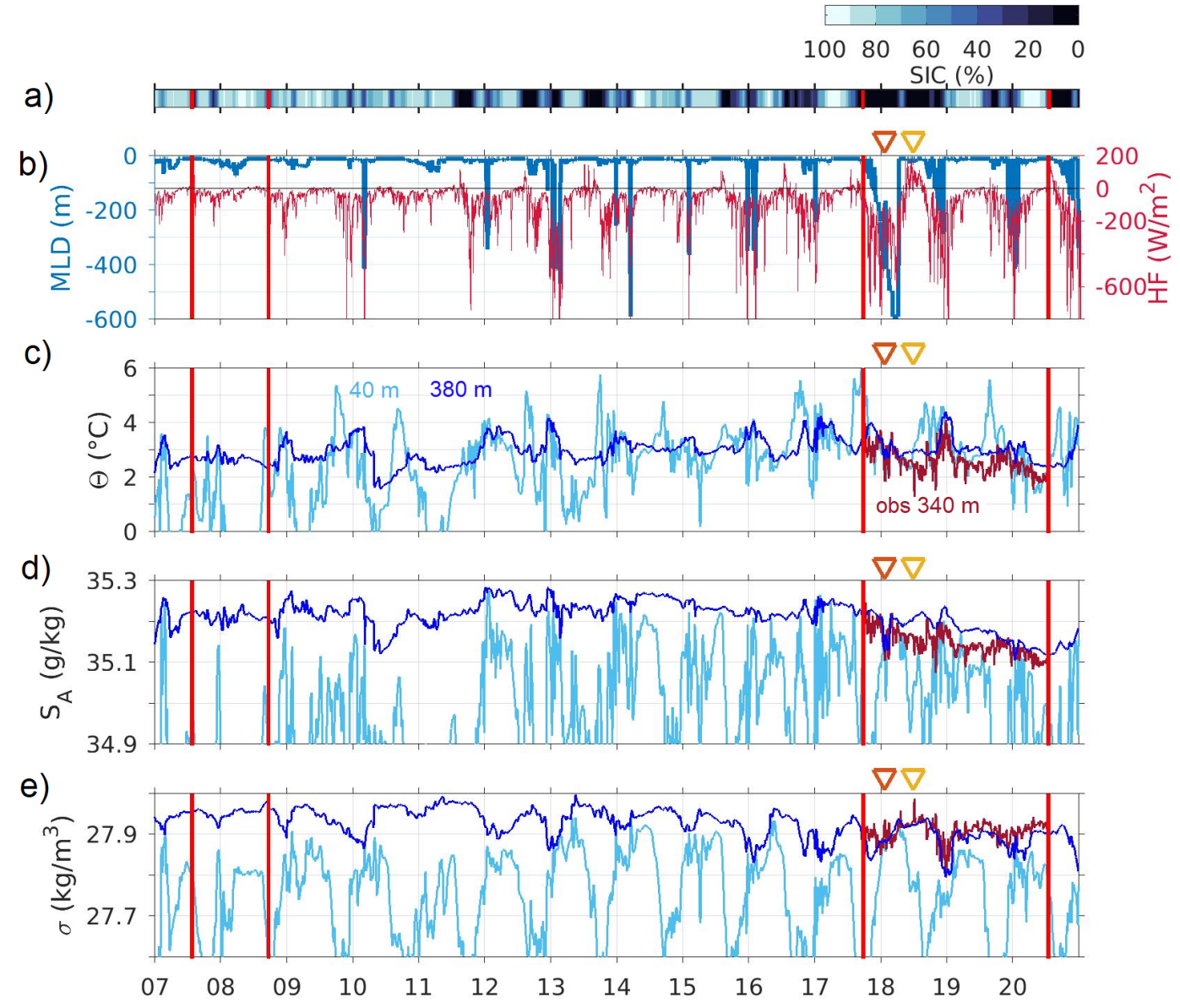

Figure 15. Time series of modelled (a) ice cover (SIC, \%). (b) Net total heat flux (HF, W/ $/ \mathrm{m}^{2}$ ) and mixed layer depth (MLD, m). (c) conservative temperature $\Theta\left({ }^{\circ} \mathrm{C}\right)$, (d) absolute salinity $S_{A}$ $(\mathrm{g} / \mathrm{kg})$ and (e) potential density $\left(\sigma, \mathrm{kg} / \mathrm{m}^{3}\right)$ from the model at $40 \mathrm{~m}$ (light blue) and $380 \mathrm{~m}$ (dark blue), and from observations at $340 \mathrm{~m}$ (red). The MLD was defined as the shallowest depth at which potential density exceeded the surface value by $0.01 \mathrm{~kg} / \mathrm{m}^{3}$. The vertical red lines indicate the moorings period. The orange and yellow triangles on the top indicate the dates of the deep convection event in January 2018 and the densest waters recorded in July 2018. 
The ice-free year 2018 stood out with a more energetic ocean state (Figure 3a, Table 2). Winter 2017-18 exhibited the largest mean velocities ever recorded in the YPB (Figure 5). Summer 2018 was characterized by an enhanced eddy-activity (Figures 5a, 5c, 7c, 7d). That summer, the ice edge was always located north of the mooring location (Figure 5). Several studies proposed that eddies may be generated and enhanced at the vicinity of the ice edge (e.g. Johannessen et al., 1987; Gascard et al., 1988) through interactions between AW and cold, fresh surface water below the ice, or via wind-induced Ekman pumping along the ice edge. Such processes could have been instrumental for the energetic eddy field recorded in summer 2018 .

The PSY4 model suggested changes in Atlantic Water routes over the Yermak Plateau from 2013 onwards (section 4.2., Athanase et al., 2021). Recirculation branches shifted to the north, while the Yermak Pass Branch and the Yermak Branch (circulating respectively over and around the western edge of the Plateau) intensified. Intermittently, a northern branch of AW (NB) crossed the Yermak Plateau north of $81.8^{\circ} \mathrm{N}$ (Figure 1b).

PSY4 featured a larger AW YPB transport during the recent 2017-2020 period than in 2007-2008 $(+40 \%)$, yet both values were below the 14-year mean. Interannual variations were important (Figure 13) likely due to the variable partitioning of the AW inflow between recirculations towards Fram Strait and branches over the Plateau (Figure 1b). For instance, the striking AW transport minimum in the YPB in 2017-18 (Figure 13 and S3) corresponded to larger recirculations recorded in Fram Strait at $80.2^{\circ} \mathrm{N}, 0^{\circ} \mathrm{E}$ (Hofmann et al., 2021).

Periods with negative net transports intermittently occurred each year except in 2014 and 2015 (red in Figure 13a). We investigated the circulation during the salient negative transports (net transport $<-0.7 \mathrm{~Sv}$ ). Those occurred in winter. We selected events with transport $<-0.7 \mathrm{~Sv}$ (corresponding to 49 days in winter) and built a composite of velocity fields (Figure 16). The composite showed a mesoscale structure leading to northward velocities $(>6 \mathrm{~cm} / \mathrm{s})$ in the proximity of the mooring. Synoptic ocean conditions resembled those depicted in Figure 11, with a very active mesoscale field associated with an intensified Yermak Branch (YB) feeding the Northern Branch (NB) (Figure 1b) north of $81.8^{\circ} \mathrm{N}$ on the Yermak Plateau. Coincidentally, an anticyclonic eddy impinged the Yermak Pass blocking the flow impeding the Yermak Pass Branch. Those periods of "blocking of the YPB", with net transport $<-0.7 \mathrm{~Sv}$, occurred more often after year 2016 likely in relation with the increase of the eddy activity (Figure 13 a). 


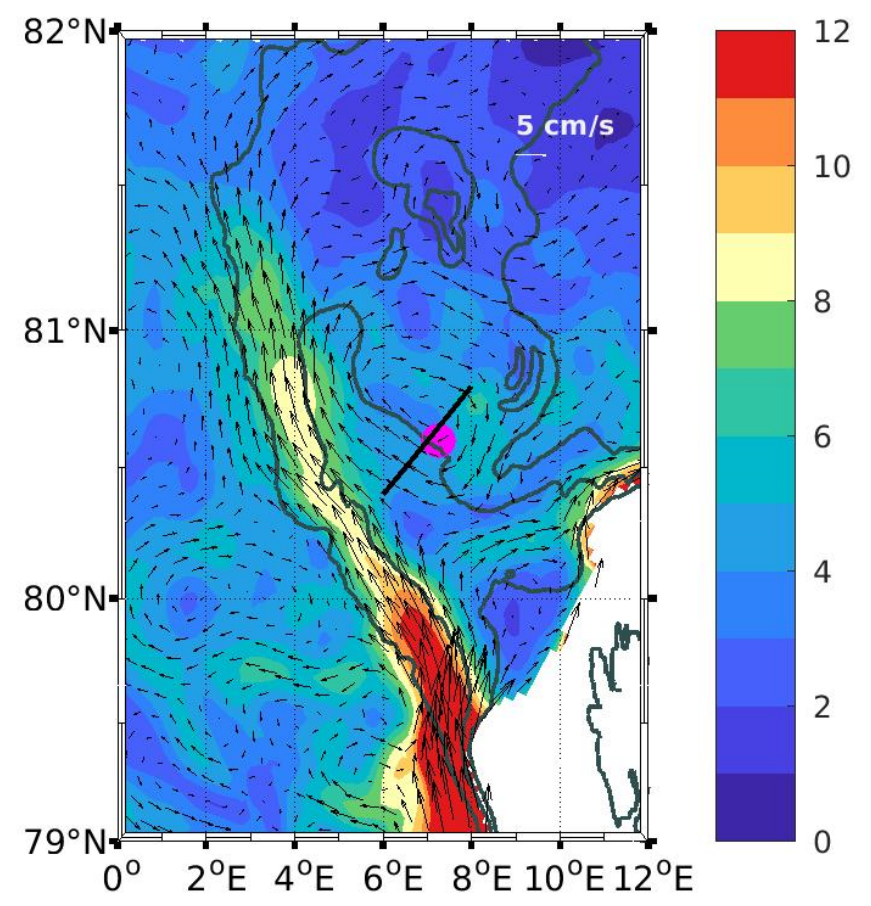

Figure 16. Velocity composite at $266 \mathrm{~m}$ associated with blocking events. The composite is built from velocities at dates with net transport $<-0.7 \mathrm{~Sv}$. 49 winter days are considered. Magenta dot indicates the mooring location and black line is the section used to compute the AW transport. Dark green contours are 1000-m, 700-m and 500-m isobaths. 


\section{Summary and conclusion}

Ten years after a pioneering mooring deployment at the same location in 2007, the 20172020 mooring data documented the evolution of the Yermak Pass Branch under "new Arctic" conditions (e.g. Carmack et al., 2015). Indeed, while sea-ice was abundant in the area during the first 2007 deployment (mean ice concentration of $74 \%$ at the mooring location), the sea ice concentration was reduced over Yermak Pass during the second deployment (39\%) (Figure 3). Time-scales larger than 50 hours were considered: high frequencies in the mooring observations will be examined in a subsequent study focusing on the large tidal and inertial activity over the Yermak Plateau (e.g. Fer et al., 2015).

The new mooring data in the Yermak Pass Branch documented larger velocity variations (40\%) in 2017-2020 than in 2007. Within the recent period (2017-2020), year 2018 stood out with the exceptionally ice-free conditions and an enhanced eddy activity, possibly favored by the vicinity of the sea-ice edge.

Stringent comparisons of the Mercator Ocean operational system (PSY4) with the 20172020 mooring data confirmed the skills of the model in reproducing variations of water mass properties and velocities (for timescale larger than 20 days within the YPB). While PSY4 was less energetic than observations, the EOFs of modelled velocities were similar to those of the mooring data.

Daily outputs from PSY4 were used to put the observations in a broader spatio-temporal context within a 14-year period (January 2007 to December 2020). The model AW transport time series through Yermak Pass had synoptic values comprised between -1 and $5 \mathrm{~Sv}$ and showed large interannual and seasonal variations. The transport was larger in winter than in summer. PSY4 provided insights on anomalous winter northward velocity events recorded by the moored ADCP leading to transport lower than $-0.7 \mathrm{~Sv}$. We called those episodes "blocking events". They were likely associated with eddy recirculations over the southern part of the Yermak Plateau, at a time of well-developed Yermak Branch and northern Branch at $81.8^{\circ} \mathrm{N}$. These "blocking" episodes were more common after 2016 as the eddy activity intensified.

PSY4 provided further insights on the water properties recorded by the in situ instrument. PSY4 suggested that the recorded negative temperature and salinity trend observed in the YPB were temporary. The dense waters observed in January 2018 were coincident 
with a long convective episode in PSY4 with deep mixed layers in excess of $400 \mathrm{~m}$ and heat fluxes from the atmosphere to the ocean on the order of $-600 \mathrm{~W} / \mathrm{m}^{2}$. PSY4 also suggested that the densest waters recorded on 7 July 2018 were associated with a mesoscale structure coming from the Sofia Deep.

Temperature and salinity measurements were only available at one level in the water column $(348 \mathrm{~m})$. Although additional instrumentation on the mooring line would have helped understanding the dynamics of the Yermak Pass Branch, the model proved to be a most useful tool to complement the in situ data. Such a synergy provided valuable insights on the recent changes in the YPB, major route for the warm AW to the Arctic.

\section{Acknowledgments}

We are deeply grateful to the officers, crews and scientists onboard the Norvegian Ressearch Vessel Lance (deployment) and Norwegian ice breaker KV Svalbard (recovery). We thank A. Sundfjord and J.C. Gascard for their constant support and help. Matthieu Labaste (LOCEAN) was instrumental in mooring preparation and logistics. We thank the two anonymous reviewers and the editor for their careful and constructive comments.

The field work was funded through the ANR EQUIPEX IAOOS project through ANR10-EQX-32-01 grant and the ICE-ARC programme from the European Union 7th Framework Programme, grant 603887. Camila Artana acknowledges support from a CNES postdoc scholarship, Marylou Athanase from a postdoc funded by the BMBF research group Seamless Sea Ice Prediction and Zoe Koenig a postdoc from the Nansen Legacy Project (number 276730). Ava Asgari's master internship was supported through the Pan Arctic Options Belmont Forum project (ANR-14-AORS-003-01).

The Mercator ocean global operational system is part of the Copernicus Marine Environment Monitoring Service (CMEMS; http://marine.copernicus.eu). The mooring data from 2007-2008 and 2017-2020 are available in the SEANOE data base: https://doi.org/10.17882/83214 and https://doi.org/10.17882/51023.

\section{References}

Aagaard, K. E. C. Carmack (1989), The role of sea ice and other fresh water in the arctic circulation. Journal of Geophysical Research, Oceans. DOI:10.1029/JC094iC10p14485 
Athanase, M., Sennéchael N., Garric G., Koenig Z., Boles E. \& Provost C. (2019). New hydrographic Measurements of the Upper Arctic Western Eurasian Basin in 2017 Reveal Fresher Mixed Layer and Shallower Warm Layer Than 2005-2012 Climatology. Journal of Geophysical Research, Oceans, DOI:10.1029/2018JC014701581

Athanase, M., Provost C., Pérez-Hernández M.D., Sennéchael N., Bertosio C., Artana C., Garric G., Lellouche J.-M. (2020). Atlantic Water modification north of Svalbard in the Mercator physical system from 2007 to 2020. Journal of Geophysical Research, Oceans, DOI:10.1029/2020JC016463

Athanase, M., Provost C., Artana C., Pérez-Hernández M.D., Sennéchael N., Bertosio C., Garric G., Lellouche J.-M., \& Prandi P. (2021). Changes in Atlantic Water Circulation Patterns and Volume Transports North of Svalbard Over the last 12 years (2008-2020). Journal of Geophysical Research, Oceans, DOI:10.1029/2020JC016825.

Beszczynska-Möller, A., Fahrbach, E., Schauer, U., \& Hansen, E. (2012). Variability in Atlantic water temperature and transport at the entrance to the Arctic Ocean, 1997-2010. ICES Journal of Marine Science. DOI:10.1093/icesjms/fss056

Cokelet, E. D., Tervalon, N., \& Bellingham, J. G. (2008). Hydrography of the west Spitsbergen Current, Svalbard Branch: autumn 2001. Journal of Geophysical, Research: Oceans. DOI:10.1029/2007JC004150606

Crews, L., Sundfjord, A., Albretsen, J., \& Hattermann, T. (2018). Mesoscale eddy activity and transport in the Atlantic Water inflow region north of Svalbard. Journal of Geophysical Research, Oceans. DOI:10.1002/2017JC013198

Crews, L., Sundfjord, A., \& Hattermann, T. (2019). How the Yermak Pass Branch regulates Atlantic Water inflow to the Arctic Ocean. Journal of Geophysical Research: Oceans. DOI:10.1029/2018JC014476

Fer, I., M., Müller, \& A. K. Peterson (2015). Tidal forcing, energetics, and mixing near the Yermak Plateau. Ocean Science. DOI:10.5194/os-11-287-2015615

Gascard, J.-C., Kergomard, C., Jeannin, P.-F., \& Fily, M. (1988). Diagnostic study of the Fram Strait marginal ice zone during summer from 1983 and 1984 Marginal ice zone experiment Lagrangian observations. Journal of Geophysical Research, Oceans. DOI:10.1029/jc093ic04p03613. 
Gascard, J.-C., Richez, C., \& Rouault, C. (1995). New insights on large-scale oceanography in Fram Strait: The West Spitsbergen Current. InW.O. Smith, Jr., J. M. Greibmeier (Eds.), Arctic oceanography, marginal ice zones and continental shelves (Vol. 49, pp. 131-182). Washington, DC: American Geophysical Union

Good, S.A., Martin M.J., \& Rayner N.A. (2013). EN4 Quality controlled ocean temperature and salinity profiles and monthly objective analyses with uncertainty estimates. Journal of Geophysical Research, Oceans, DOI:10.1002/2013JC009067.

Hattermann, T., Isachsen, P. E., von Appen, W.-J., Albretsen, J., \& Sundfjord, A. (2016). Eddy-driven recirculation of Atlantic Water in Fram Strait. Geophysical Research Letters. DOI:10.1002/2016GL068323623

Henley S.F., Porter M., Hobbs L., Braun J., Guillaume-Castel R., Venables E.J., Dumont E., \& Cottier F. (2020). Nitrate supply and uptake in the Atlantic Arctic sea ice zone: seasonal cycle, mechanisms and drivers. Phil. Trans. R. Soc. A, DOI:10.1098/rsta.2019.0361

Hofmann, Z., von Appen, W.-J., \& Wekerle, C. (2021). Seasonal and mesoscale variability of the two Atlantic Water recirculation pathways in Fram Strait. Journal of Geophysical Research, Oceans. DOI:10.1029/2020JC017057

Holliday, N. P., Bersch, M., Berx, B., Chafik, L., Cunningham, S., et al. (2020). Ocean circulation causes the largest freshening event for 120 years in Eastern Subpolar North Atlantic. Nature communications. DOI:0.1038/s41467-020-14474-y

Ivanov, V., Smirnov A., Alexeev, V., Koldunov, N.V., Repina, I, \& Semenov, V. (2018). Contribution of convection-induced heat flux to winter ice decay in the western Nansen Basin. Journal of Geophysical Research, Oceans, DOI:10.1029/2018JC013995.

Jakobsson, M., Mayer, L., Coakley, B., Dowdeswell, J. A., Forbes, S., Fridman, B., \& Weatherall, P.(2012). The International Bathymetric Chart of the Arctic Ocean (IBCAO) Version 3.0. Geophysical Research Letters,39. DOI:48010.1029/2012gl05221

Johannessen, J. A., Johannessen, O. M., Svendsen, E., Shuchman, R., Manley, T. O., Campbell, W. J., et al. (1987). Mesoscale Eddies in the Fram Strait Marginal Ice Zone during the 1983 and 1984 marginal ice zone experiments. Journal of Geophysical Research, DOI:10.1029/JC092iC07p06754 
Koenig, Z., Provost, C., Sennéchael, N., Garric, G., \& Gascard, J.-C. (2017). The Yermak Pass Branch: A major pathway for the Atlantic Water North of Svalbard? Journal of Geophysical Research, Oceans. DOI:10.1002/2017JC013271631

Koenig, Z., Provost, C., Villacieros-Robineau, N., Sennéchael, N., Meyer, A., Lellouche, J.-M., \& Garric, G. (2017). Atlantic Waters inflow north of Svalbard: Insights from IAOOS observations and Mercator ocean global operational system during N-ICE 2015. Journal of Geophysical Research, Oceans, DOI:10.1002/2016JC012424

Lellouche, J.M., Greiner, E., Le Galloudec, O., Garric, G., Regnier, C., Drevillon, M., Le Traon, P.-Y., et al. (2018). Recent updates to the Copernicus marine service global ocean monitoring and forecasting real-time 1/12 high-resolution system. Ocean Science, DOI:10.5194/os-14-1093-2018

Lundesgaard, Ø., Sundfjord, A., \& Renner, A. H. H. (2021). Drivers of interannual sea ice concentration variability in the Atlantic Water inflow region north of Svalbard. Journal of Geophysical Research, Oceans, DOI:10.1029/2020JC016522

Lupkes, C., \& Birnbaum, G. (2005). Surface drag in the arctic marginal sea-ice zone:507a comparison of different parameterisation concepts.Boundary-layer meteorol-508ogy,117(2), 179-211. DOI: $10.1007 / \mathrm{s} 10546-005-1445-8$

Manley, T. (1995). Branching of Atlantic Water within the Greenland-Spitsbergen passage: an estimate of recirculation. Journal of Geophysical Research, Oceans,DOI:10.1029/95JC01251651

McDougall, T. J., P. M., Barker, (2011). Getting started with teos-10 and the Gibbs seawater (gsw) oceanographic toolbox. SCOR/IAPSO WG, 127, 1-28

Mork, K.A., Skagseth Ø. \& Søiland H. (2019). Recent Warming and Freshening of the Norwegian Sea Observed by Argo Data. Journal of Climate. DOI:10.1175/JCLI-D-180591.1

Nurser, A. J. G. \& Bacon, S. (2014). The Rossby radius in the Arctic Ocean, Ocean Science, 10, 967-975, DOI:10.5194/os-10-967-2014.

Onarheim, I. H., Smedsrud, L. H., Ingvaldsen, R. B., Nilsen, F. (2014). Loss of sea ice during winter North of Svalbard. Tellus A: Dynamic Meteorology and Oceanography. DOI:10.3402/tellusa.v66.23933 
Padman, L., Plueddemann, A. J., Muench, R. D., \& Pinkel, R. (1992). Diurnal tides near the Yermak Plateau. Journal Geophysical Research, Oceans. DOI:10.1029/92JC01097

Pérez-Hernàndez, M. D., R. S., Pickart, D. J., Torres, F., Bahr, A., Sundfjord, R., Ingvaldsen, V., Pavlov, (2019). Structure, transport, and seasonality of the Atlantic Water Boundary Current North of Svalbard: Results from a yearlong mooring array. Journal of Geophysical Research: Oceans. DOI:10.1029/2018JC014759

Polyakov, I. V., Pnyushkov, A. V., Alkire, M. B., Ashik, I. M., Baumann, T. M., Carmack, E. C., et al. (2017). Greater role for Atlantic inflows on sea-ice loss in the Eurasian Basin of the Arctic Ocean. Science. DOI:10.1126/science.aai8204681

Polyakov, I. V., Rippeth, T. P., Fer, I., Alkire, M. B., Baumann, T. M., Carmack, E. C., et al. (2020). Weakening of cold halocline layer exposes sea ice to oceanic heat in the Eastern Arctic Ocean. Journal of Climate. DOI:10.1175/JCLI-D-19-0976.1685

Richez C. (1998). The West Spitzbergen Current as seen by SOFAR floats during ARCTEMIZ 88 Experiment: Statistics, differential kinematic properties, and potential vorticity balance. Journal of Geophysical Research, Oceans. DOI:10.1029/97JC02412.

Teigen, S. H., Nilsen, F., Skogseth, R., Gjevik, B., \& Beszczynska-Möller, A. (2011) Baroclinic instability in the West Spitsbergen Current. Journal of Geophysical Research, Oceans. DOI:10.1029/2011JC006974

Wekerle, C., Wang, Q., von Appen, W.-J., Danilov, S., Schourup-Kristensen, V., \& Jung, T. (2017). Eddy-resolving simulation of the Atlantic Water circulation in the Fram Strait with focus on the seasonal cycle. Journal of Geophysical Research, Oceans. DOI:10.1002/2017JC012974 